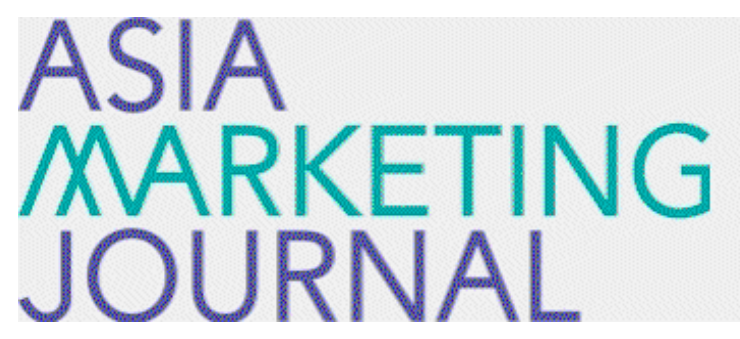

ASIA MARKETING JOURNAL

Volume 8 | Issue 3

Article 8

10-30-2006

\title{
빙그레 요플레의 시장 선도적 신제품 마케팅전략
}

So Young Kim

Heon Soo Jung

Young Chan Kim

Follow this and additional works at: https://amj.kma.re.kr/journal

Part of the Marketing Commons

\section{Recommended Citation}

Kim, So Young; Jung, Heon Soo; and Kim, Young Chan (2006) "빙그레 요플레의 시장 선도적 신제품 마케팅 전략," Asia Marketing Journal: Vol. 8 : Iss. 3 , Article 8.

Available at: https://doi.org/10.53728/2765-6500.1177

This Article is brought to you for free and open access by Asia Marketing Journal. It has been accepted for inclusion in Asia Marketing Journal by an authorized editor of Asia Marketing Journal. 


\title{
빙그레 요플레의 시장 선도적 신제품 마케팅전략
}

\author{
Marketing Strategy of New Product for Market Leader: \\ Binggrae Yoplait Case
}

김 소 영(Kim, So Young)*
정 헌 수(Jung, Heonsoo)**
김 영 찬(Kim, Youngchan)***

빙그레는 국내 최초로 떠먹는 요구르트인 요플레를 출시한 후 지금까지 요구르트시장에서 요플레 의 막강한 브랜드 파워와 함께 확고한 시장지위를 차지하고 있다. 본 연구에서는 더욱 치열해지고 있 는 요구르트시장의 경쟁 속에서 빙그레가 시장선도자(떠먹는 요구르트시장)로서 또한 시장후발주자 (드링킹 요구르트시장)로서 어떻게 시장을 개척하고 대응해왔는지를 분석하였다. 연구 결과, 빙그레 요플레는 기존의 경쟁논리에 얽매이지 않고 새로운 가치를 제공하면서 시장의 경쟁패러다임을 변화 시키기 위해 시장을 선도하는 차별적인 신제품 마케팅전략을 실시하고 있음을 알 수 있었다.

앞으로도 빙그레 요플레는 장기적으로 요플레의 브랜드 자산을 관리하기 위한 보다 정교한 마케팅 전략적 관리와 함께 시장을 이끌어가기 위한 지속적인 마케팅 노력이 병행되어야 할 것이다.

핵심개념: 빙그레 요플레, 마케팅전략, 신제품 개발, 요구르트시장

\section{I. 서 론}

1983년 국내 최초로 떠먹는 요구르트로 출시 된 빙그레 요플레는 정통 호상 요구르트의 새 로운 시작을 알리며 국내 요구르트 산업을 한 단계 도약시킨 제품이다. 국내에서 떠먹는 요구 르트의 대명사로 통하고 있는 요플레는 막강한
브랜드 파워를 보유하면서 요구르트시장에서 확고한 시장지위를 차지하고 있다.

그러나 국내 요구르트시장의 경우 기능성을 강화한 드링킹 요구르트시장의 급성장으로 인 해 외국 시장과는 달리 떠먹는 요구르트제품에 대한 저가 이미지 형성과 함께 시장자체가 정 체되는 반면 드링킹 요구르트는 건강에 좋은 제품으로 시장이 확대되는 어려운 상황에 직면

* 숙명여자대학교 경영학부 조교수(kimsy@sm.ac.kr)

** 건국대학교 경영대학 조교수(hjungkor@konkuk.ac.kr), 교신저자

*** 연세대학교 경영대학 교수(youngkim@yonsei.ac.kr) 
하게 되었다. 빙그레는 떠먹는 요구르트시장의 선두주자로서 시장의 정체를 해결해야할 뿐 아 니라 드링킹 요구르트시장의 후발주자로서 소 비적인 경쟁을 피하고 빙그레에 유리한 새로운 경쟁구도를 만들어내야 하는 과제 해결까지 이 중부담을 안게 되었다.

이러한 상황에서 빙그레는 어떠한 마케팅전략 을 실시해야 하는 것일까? 빙그레는 떠먹는 요 구르트시장과 드링킹 요구르트시장에서 시장 선도자로서 또한 시장 후발주자로서 기존의 경 쟁논리에 얽매이지 않고 새로운 가치를 제공하 면서 시장의 경쟁패러다임을 변화하기 위한 시 장 선도적 신제품 마케팅전략을 실시하였다. 그 결과 떠먹는 요구르트시장이 2006년 상반기에 는 그동안의 정체를 벗어나 $8.5 \%$ 의 양호한 성 장세를 나타내게 되었으며, 드링킹 요구르트시 장에서도 현재까지 확고한 시장지위를 유지하 는 성과를 거두었다고 볼 수 있다.

이에 본 연구의 목표는 빙그레의 기본적인 제 품전략과 함께 시장의 선도주자로서 그리고 후 발주자로서 어떻게 시장선도적인 신제품 마케 팅 전략을 실행했는지를 분석하고, 이를 통해 다른 기업에서도 신제품 마케팅의 전략적 시사 점을 얻을 수 있도록 하는 것이다.

\section{II. 빙그레의 전략환경}

\section{1 빙그레의 연혁}

빙그레는 1967년 대일양행이라는 상호로 출발 하여 1982년 CI 변경을 통해 현재의 상호인 빙
그레로 사명을 확정하였으며, 1992년 한화그룹 에서 분리 독립하였다. 분리 독립했을 당시 부 채비율이 4,183\%였으나, 1996년의 사업구조 재 편, 압구정 사옥 매각을 비롯한 자산 구조조정, 비수익 브랜드 정리, 1992년 3,000명에 달하던 인력을 2004년 말 기준 1700 명으로 슬림화하는 등 전방위적인 구조조정을 시행하였고, 특히 2000년 이후 수익중심의 경영 패러다임 정착, 핵심 역량 중심의 사업구조, 시스템 경영의 확 립, 미래지향적 조직문화 구축, 상생의 노사관 계 확립을 목표로 설정하여, 끊임없는 구조조정 을 시행해 왔다. 이러한 구조조정의 결과로 2003년 배당주가지수 50종목(KODI)과 기업지 배구조지수(KOGI) 종목으로 선정된 후, 2004 년 결산시점에는 $53.7 \%$ 로 부채비율을 개선시켰 다. 비수익 브랜드에 대한 구조조정에서는 핵심 역량에 집중하여 수익성을 기준으로 비수익 사 업군의 매각과 정리를 단행하면서, 주요 사업군 인 유음료와 아이스크림 사업을 제외한 라면과 제빵사업을 정리하고, 수익을 창출해내는 사업 분야이면서 동시에 가장 전문성이 있다고 판단 한 유음료 사업에 집중하기로 하였다.

현재 빙그레에는 1,700 여명의 본사와 공장 임 직원이 있으며, 경기도 남양주시의 $1,2,3$ 공장 과 경기도 광주, 논산, 김해 공장까지 총 6 개의 공장과 경상북도 경산에 위치한 물류센터를 소 유하고 있다. 또한 전국 1,000 여 개의 유제품 대리점과 아이스크림 영업소 등을 포함한 유통 망과 자체 연구소를 가지고 있다.

\section{2 빙그레의 비전 및 철학}

빙그레는 근심도 없고, 설움도 없으며, 가책이 


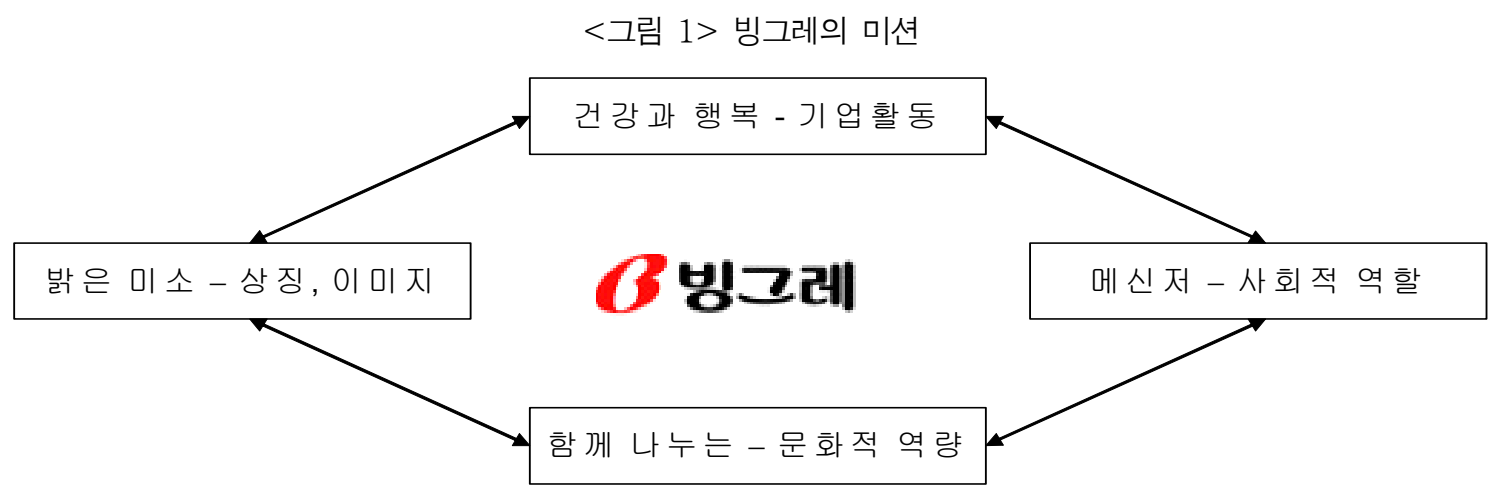

나 혼탁이 없는 양심에서 우러나오는 민족의 웃음을 뜻하는 도산 안창호 선생의 빙그레 사 상을 근간으로 하고 있다. 이는 국내외의 동종 업계 뿐만이 아닌 어느 기업과도 차별화 되는 것이다. 빙그레는 단순히 먹거리를 제조 판매하 는 기업이 아닌 대한민국 사회의 일원으로서 국가와 민족의 안녕에 기여하고자 하는 사회지 향적, 민족중심적 기업 철학을 보유하고 있다. 이러한 기본 철학은 2000 년에 시행한 비전 선 포식에서 공식화 된 기업의 미션에 잘 드러나 있다.

빙그레는 기업의 미션을 기업의 존재이유를 말하는 것으로 경영의 핵심 목적이자 기업의 자아실현 목표이며, 사회에 대하여 어떠한 기여 를 할 것인가를 천명하는 기업의 정신을 표현 하는 것으로 정의하며, '건강과 행복을 함께 나 누는, 밝은 미소의 메신저'로 선포하였다. '건강 과 행복'은 빙그레 기업 활동의 지향점을, '함께 나누는'은 기업 문화적 역량을, '밝은 미소'는 빙그레의 상징이며 대내외적 이미지를 표현한 것이고, '메신저'라는 단어는 기여자, 공헌자라 는 사회적 역할을 의미한다. 이러한 사명과 기
업의 미션을 통해 2011년에는 매출액 2조 5천 억 원, 순이익 3 천억 원의 글로벌 기업이 되겠다 는 비전을 갖고 있다.

\section{3 요구르트시장의 시장구도}

\section{3 .1 해외 요구르트시장}

세계 요구르트 시장규모는 2001년 기준으로 약 18 백만 톤, 360 억 유로 수준으로 해마다 5\% 이상의 견고한 성장세를 나타내고 있다. 전체 시장의 $35 \sim 40 \%$ 는 다농(프랑스)을 선두로 하 여 요플레(프랑스), 네슬레(스위스), 야쿠르트 (일본) 등의 글로벌 브랜드가 점유하고 있으며 나머지 시장을 국가별 현지 브랜드들이 점유하 는 형태를 보이고 있다(<그림 2>참조). ${ }^{1)}$

이들 시장은 매우 다양하게 세분화되어 있는 데, 예를 들면 플레인 요구르트, 기능성 컵 요 구르트, 기능성 드링킹 요구르트, 무지방 요구 르트, 레귤러 과일 요구르트, No-bit 요구르트 (과육미포함), 스페셜티, 어린이용 드링킹 요구 르트, 식사대용 드링킹 요구르트, 유아/어린이

1) 시장점유율 기준으로는 다농이 1 위이며, 시장 커버리지(market coverage)로는 요플레가 1 위임. 
<그림 2> 글로벌 지역별 요구르트시장의 구성비

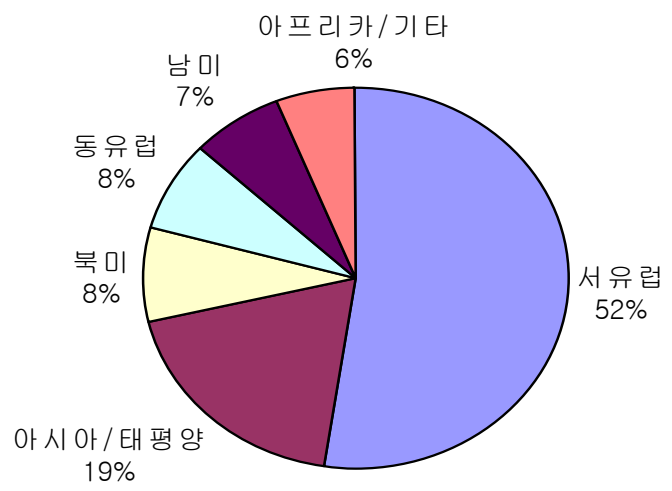

용 떠먹는 요구르트 등이 있다. 해외 요구르트 시장은 대부분 떠먹는 요구르트가 주종을 이루 고 있으며, 세계에서 가장 큰 시장 중의 하나인 프랑스의 경우에도 드링킹 요구르트의 유형별 점유율은 $13 \%$ 내외에 불과하다. 또한 해외 시 장은 무지방/저지방 제품의 비중이 매우 높은 데, 이는 요구르트 섭취량이 매우 많기에 아시 아 등 다른 지역시장에 비해 지방 함량에 대한 관여도가 매우 높기 때문이라고 해석할 수 있 다(<표 $1>$ 참조).

요구르트시장의 2005 2006년 글로벌 트렌드 는 크게 네 가지로 요약할 수 있는 데, (1)무지 방 요구르트의 침체, (2)과일 요구르트 중 레귤 러의 감소 및 프리미엄군의 성장, (3)기능성 요 구르트시장의 지속적인 신장세 (4)유기농 자연 주의 요구르트의 급신장(두 자릿수 성장률)으 로 표현할 수 있다.

\subsection{2 국내 요구르트시장}

1) 국내 요구르트시장의 특징

국내 요구르트시장은 크게 액상, 떠먹는 요구 르트(호상), 드링킹 요구르트의 세 개 카테고리 로 분류된다. 과거에는 요구르트하면 소형 플라 스틱 통에 담긴 살색의 액상 요구르트가 전부 였다. 액상 요구르트로는 한국야쿠르트가 1971 년 국내 최초로 출시한 '야쿠르트’가 대표 제품 이며, 이후 94년 한국야쿠르트 '야쿠르트 에이 스', 96년 남양 '이오' 등 영양성분을 첨가한 고 급 액상 요구르트로 시장이 확대되었다. 요구르 트 선진지역에서 발달해있는 떠먹는 형태의 호 상 요구르트가 국내에 최초로 소개된 것은 1983년으로 빙그레 ‘요플레’가 효시였다. 이는 기존 액상 요구르트와는 확연히 맛이 다른 농 후요구르트였기 때문에 소비자의 호응을 얻고 시장에 정착하는데 오랜 시간이 소요되었지만, 1990년대 중반까지 그 인기는 매우 높았다.

현재 가장 큰 시장을 형성하고 있는 드링킹 요구르트는 88년 '파스퇴르 요구르트'로 시작되 어, 90년 남양 '불가리스', 95년 한국야쿠르트 '메치니코프', 97년 빙그레 '닥터캡슐' 등이 출시 되면서 1990년대 말부터 요구르트시장을 주도 하게 되었다. 드링킹 요구르트시장은 2000년 또 한 차례의 확장기를 맞이한다. 한국야쿠르트의 '윌'이 장 건강에 좋다는 요구르트의 전통적인 특성에 부가하여 위 건강까지 돕는 제품으로

<표 1> 국가별 요구르트 소비량

\begin{tabular}{|c|c|c|c|c|}
\hline & 호주 & 영국 & 프랑스 & 한국 \\
\hline 2005년 인당 소비량 $(\mathrm{Kg})$ & 8.5 & 12.0 & 28.0 & 4.6 \\
\hline
\end{tabular}


<표 2> 국내 요구르트시장 규모

(단위: 억 원)

\begin{tabular}{|c|c|c|c|c|c|c|}
\hline \multirow{2}{*}{$\begin{array}{c}\text { 떠먹는 } \\
\text { 요구르트 }\end{array}$} & \multicolumn{5}{|c|}{ 드링킹 요구르트 } & 짜먹는 \\
\cline { 2 - 6 } & 장 & 위 & 간 & 기타르트 & 소계 & 130 \\
\hline 1490 & 2270 & 1350 & 580 & 90 & 4290 & 130 \\
\hline
\end{tabular}

등장한 것이다. 이후 드링킹 요구르트는 2004년 한국야쿠르트가 '쿠퍼스'를 출시하며 간 영역까 지 확장되었고, 이후 경쟁사에서 혈압, 당뇨 등 에 이르기까지 다양한 기능성의 제품들을 선보 이고 있다. 이 같이 기능성을 강화한 드링킹 요 구르트시장의 급성장으로 인해 액상과 떠먹는 요구르트시장은 수년간 정체를 보이고 있다.

국내 요구르트시장은 해외 요구르트시장과 비 교하여 두 가지 뚜렷한 특징이 있는 데, (1) 드 링킹 요구르트가 전체의 $73 \%$ (액상요구르트시 장 제외 시)를 차지하며(<표 2> 참조), (2) 야 쿠르트가 주도하는 방문판매(이후 방판) 시장 이 전체의 $45 \%$ 수준에 이른다는 것이다. 이러 한 독특한 시장 구조는 우선, 야쿠르트의 방판 이라는 유통 특성에서 그 원인을 찾을 수 있다. 거대한 방판 조직을 거느린 야쿠르트는 조직 운영을 위하여 필연적으로 고수익성 제품 개발 에 주력하고 있으며, 이 같은 고수익성 제품으 로 성공하기 위해서는 기능성 제품으로 포지셔 닝하는 것이 효과적이고, 이들 기능성 고가 제 품은 방판 조직의 대인 판매망을 통해 효과적 으로 시장에 침투할 수 있었기 때문이다. 이외 에도 전통적으로 국거리 식문화가 자리 잡은 한국에서는 마시는 형태가 더 친숙하다는 점을 들 수 있다. 이러한 이유로 인해 국내 요구르트 시장의 경우, 해외 시장에서는 떠먹는 요구르트 가 가장 큰 시장을 형성하고 있는 것과는 달리 드링킹 요구르트가 가장 큰 시장을 형성하고
있다.

2) 국내 요구르트시장의 경쟁구도(액상 요 구르트시장은 제외)

국내 요구르트시장의 주요 참여회사는 한국야 쿠르트, 빙그레, 남양, 매일, 롯데, 서울우유 등 이 있으며, 이 밖에도 파스퇴르, $\mathrm{DM}$ 푸드, 해태 유업, 부산우유 등이 중소규모로 요구르트 사업 을 영위하고 있다. 이들 6 개사의 주요 요구르트 브랜드는 <표 $3>$ 과 같다.

요구르트 시장규모는 192,000 톤, 5,900억 원 수준이며, 시장점유율(2005년도 기준)을 보면, 야쿠르트 $44 \%$ 로 1위, 다음으로 남양유업과 빙 그레가 각각 $17 \%$ 와 $16 \%$ 를 차지해 2 위군을 형 성하고 있으며, 매일유업 $9 \%$, 롯데와 서울우유 모두 $7 \%$ 를 나타내고 있다.

\section{III. 빙그레 요플레의 기본적인 제품전략}

\section{1 빙그레 요플레의 브랜드전략}

빙그레 요플레 브랜드의 역사를 살펴보면, 1983년 프랑스 SODIMA사와 기술 제휴를 통해 국내 최초 떠먹는 요구르트로 출시된 요플레는 액상 요구르트 일색이던 시장에 정통 호상 요 
<표 3> 국내의 주요 요구르트 브랜드(2006년 상반기 기준)

\begin{tabular}{|c|c|c|c|c|c|c|}
\hline & \multirow{2}{*}{$\begin{array}{l}\text { 떠먹는 } \\
\text { 요구르트 }\end{array}$} & \multicolumn{4}{|c|}{ 드링킹 } & \multirow{2}{*}{$\begin{array}{l}\text { 짜먹는 } \\
\text { 요구르트 }\end{array}$} \\
\hline & & 장 & 위 & 간 & 기타 & \\
\hline 야쿠르트 & 슈퍼100 & 메치니코프 & 윌 & 쿠퍼스 & - & - \\
\hline $\begin{array}{l}\text { 빙그레 } \\
\text { (요플레) }\end{array}$ & $\begin{array}{c}\text { 오리지널 } \\
\text { 클래식 } \\
\text { 스위벨 } \\
\text { 퓨엔 }\end{array}$ & $\begin{array}{l}\text { 닥터캡슐 } \\
\text { 장의힘 }\end{array}$ & - & - & 5색5감 & 고거트 \\
\hline 남양유업 & 꼬모 & 불가리스 & 위력 & - & $\begin{array}{c}12080 \\
\text { 닥터인슈 } \\
\text { 나이스데이 }\end{array}$ & 리쪼 \\
\hline 매일유업 & 바이오거트 & $\begin{array}{c}\text { Probio GG } \\
\text { 도마슈노 }\end{array}$ & 구트 & 구트HD-1 & 후르츠 & - \\
\hline 롯데햄우유 & $\begin{array}{l}\text { 후레쉬 } \\
\text { 투앤투 } \\
\text { 루테리 } \\
\text { RB135 }\end{array}$ & $\begin{array}{c}\text { 비피더스 } \\
\text { 장에는 } 5 \text { 일 } \\
\text { 루테리 }\end{array}$ & - & - & - & - \\
\hline 서울우유 & $\begin{array}{l}\text { 요델리퀸 } \\
\text { 비요뜨 }\end{array}$ & 칸 & - & - & 퓨오레 & 짜요짜요 \\
\hline 기타 & $\begin{array}{l}\text { 생크림 } \\
\text { 벨루스 } \\
\text { 덴마크 }\end{array}$ & $\begin{array}{c}\text { 쾌변 } \\
\text { 사과요구르트 } \\
\text { 웰리스트 }\end{array}$ & 위화장력 & - & DM드링킹 & - \\
\hline
\end{tabular}

구르트의 시작을 알리며 국내 요구르트 산업을 한 단계 도약시킨 제품이라 할 수 있다. 국내에 서는 떠먹는 요구르트의 대명사로 통하지만, 사 실 요플레는 전 세계 45 개국이 함께 즐기는 요 구르트의 패밀리브랜드이다. 1965년 프랑스의 6 개 협동조합이 모여 출발한 요플레는 세계 최 초로 과일이 함유된 요구르트를 소개하였고, 이 후로 지금까지 프랑스, 미국, 캐나다, 호주, 영 국, 멕시코 등 전 세계 45 개국에서 지속적인 제 품개선 및 개발을 통해 최고의 기술력과 맛을 유지 발전시키고 있다.

요플레는 떠먹는 요구르트를 통칭하는 일반명
사로 불릴 정도의 막강한 브랜드 파워를 보유 하고 있지만, 거기에만 머무른다면 성장성에는 한계가 있을 것이다. 이에 빙그레에서는 요플레 를 떠먹는 요구르트만의 브랜드가 아니라 빙그 레에서 출시하는 모든 요구르트에 요플레의 후 광효과를 내기위한 패밀리브랜드 전략을 구사 하기로 한다. 높은 인지도와 친숙성 등 요플레 의 강력한 브랜드 가치를 요구르트제품 전반에 확산시켜 후광효과를 기대하고자 하는 것이다. 이렇게 요플레를 토대로 요구르트 전문 브랜드 로서의 이미지를 확고하게 구축함과 동시에 신 규 하위브랜드의 출시와 새로운 커뮤니케이션 
<그림 3> 요플레의 브랜드 구조 브랜드구조

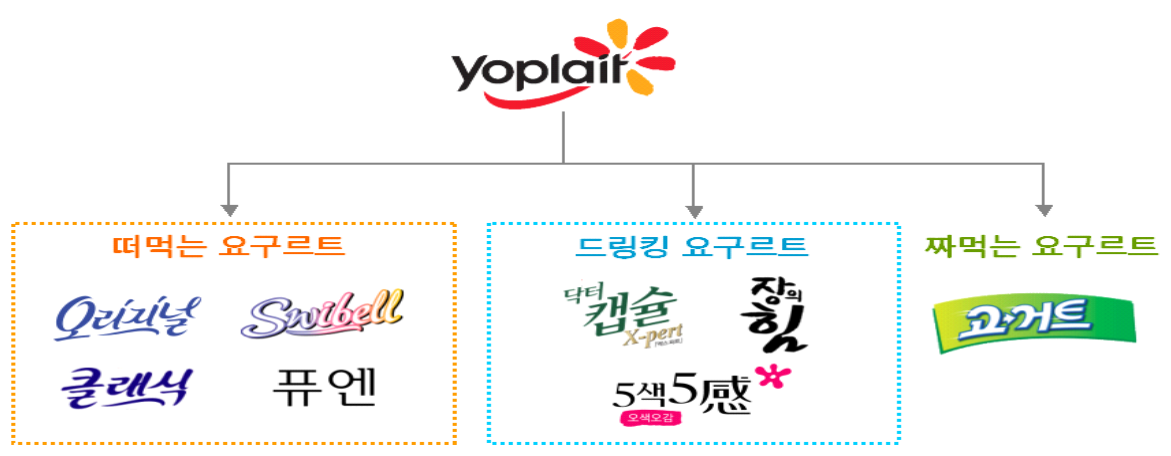

을 통해 장수 브랜드로서의 다소 정체된 이미 지를 지닌 요플레 브랜드에도 신선한 이미지를 부여하여 요플레와 신규 브랜드 모두 윈윈 (win-win)할 수 있도록 만들고자 하는 것이다. 요플레는 패밀리브랜드로서 시장에 연착륙하 기 위해 단계적 접근을 하고 있다. 1단계로 요 플레로 불려지던 제품에 2004년부터 떠먹는 요 구르트의 원조라는 의미에서 '오리지널'이라는 하위 브랜드를 붙였다. 요플레와 '떠먹는 요구 르트와 거리 만들기'가 1단계였다면, 2 단계에서 는 다소 정체된 이미지의 요플레 브랜드에 신 제품 출시를 통해 새롭고 신선한 이미지를 꾀 하는 것이라 하겠다. 스위벨, 오색오감, 퓨엔 등 새로운 세분시장을 공략하기 위해 출시된 신제 품에 요플레의 신규로고를 적용하여, 신제품에 는 요플레의 후광효과를 부여하고 요플레 브랜 드에는 새로움과 확장가능성에 대한 소비자 관 심을 유도하고자 하였다. 3단계는 요구르트제품 의 패밀리브랜드인 요플레에 대한 커뮤니케이 션을 활성화하는 단계라고 할 수 있다. 2006년 은 2 단계와 3 단계의 중간 단계로 모든 요구르 트 제품 광고에 요플레 end-cut을 공통으로 적 용하고, 요플레 홈페이지를 요구르트 전문 사이
트로서 운영하는 등의 커뮤니케이션을 진행하 고 있다. 이제 2007년부터는 본격적으로 보다 직접적인 커뮤니케이션을 통해 요플레 브랜드 이미지를 구축해나갈 예정이다.

\section{2 빙그레 요플레의 신제품 마케팅}

빙그레 요플레는 시장에서 선도적인 지위를 유지하거나 추종자로서 선도제품을 추격하기 위해 체계적인 신제품 마케팅을 실시하고 있다. 우선, 빙그레의 체계적인 신제품 개발과정을 설명하고, 이 같은 과정과 함께 빙그레가 신제 품 개발 시 추가적으로 활용하는 전략적 의사 결정 툴에 대해서도 살펴보기로 한다.

\subsection{1 빙그레의 체계적인 신제품개발 과정}

빙그레는 <그림 4>의 Cooper(1988)가 제시한 Stage \& Gate 방식을 토대로 신제품개발 과정 을 정립하였다. 그러나 빠르게 변화하는 시장환 경과 식품산업의 제품수명주기가 점차 짧아지 고 있다는 점을 감안하여, 빙그레의 기업 특성 에 적합한 형태로 Stage \& Gate 방식을 변경한 
$<$ 그림 4> Stage \& Gate 신제품개발 과정

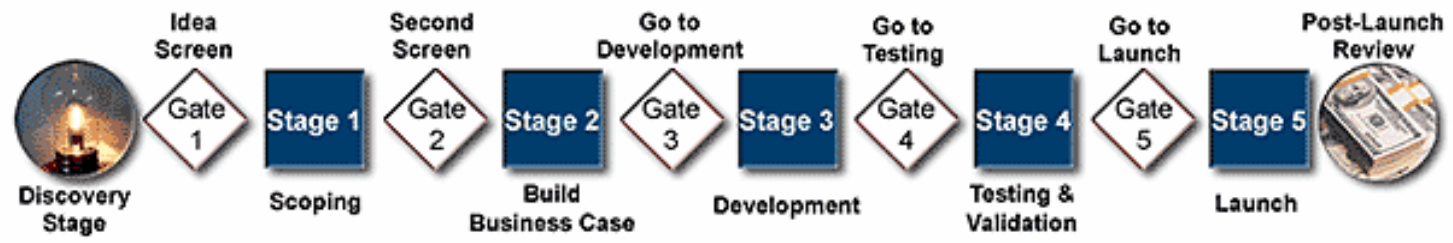

출처: Robert G. Cooper, Winning at New Products, Perseus Books Group, 1988.

신제품 개발단계를 사용하고 있다(<그림 5> 참조).

1) 시장 분석

마케팅 담당자는 전사적 정보 채널을 활용하 여, 시장에 대한 지속적이고 세부적인 분석을 수행한다. 마케팅의 기본적인 $3 \mathrm{C}$ (consumer, competiter, company) 분석을 바탕으로 급변하 는 환경변화에 적응하기 위한 시장 트렌드와 유통환경의 변화에 대한 분석을 상시 수행하며, 동시에 거시경제에 대한 분석을 수행한다. 또한 마케팅 ROI 분석을 통하여 보다 효율적인 비용
과 예산관리 업무를 수행한다. 이 같은 지속적 시장분석은 제품 아이디어 개발 차원뿐 아니라 제품개발의 시간적 흐름에 따른 시장변화에 빠 르게 대응할 수 있게 만들어준다.

2) 요플레 네트워크의 활용

빙그레 요구르트제품의 경우 타제품과는 상이 한 과정이 추가되는데, 그것은 바로 전 세계 45 개국이 참가하는 요플레 글로벌 네트워크를 통 한 정보 수집 및 공유, 마케팅 전략에의 활용이 그것이다. 요플레 마케팅 담당자의 경우, 프랑

$<$ 그림 $5>$ 빙그레의 신제품 개발 단계

\section{3 빙그레 yoplait}

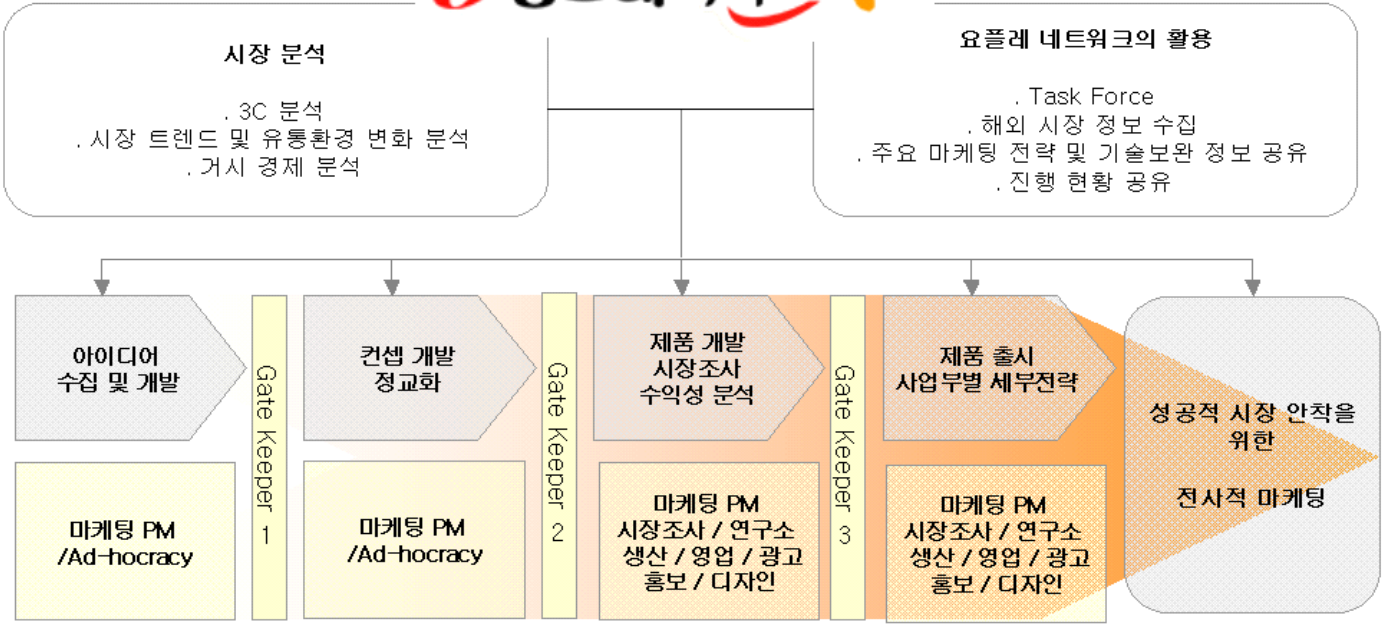


스 요플레 본사인 SODIMA사와의 커뮤니케이 션을 통한 신제품 개발 및 마케팅 활동에 대한 의견 조율과 함께, 요플레 네트워크 정보공유시 스템을 통해 해외 시장 트렌드에 대한 정보를 신속하게 수용하고 있다. 또한 각국의 마케팅과 $\mathrm{R \& D}$ 실무자들로 구성된 $\mathrm{TF}$ (Task Force)로 부터 $\mathrm{CEO}$ 급의 정기 미팅에 이르기까지 글로벌 네트워크 내 활발한 커뮤니케이션을 통하여 신 제품 공동개발이 이루어지기도 하며, 각국의 성 공 및 실패사례를 토대로 국내 시장에 적합한 마케팅 전략으로 수정·적용하는 등 글로벌 네 트워크를 적극 활용하고 있다.

3) 제품 개발 및 출시의 $S \& G$ 프로세스 마케팅 담당자는 앞서 말한 시장분석 및 요플 레 글로벌 네트워크를 통한 정보를 바탕으로 아이디어의 수집 및 선정을 시작한다. 이 단계 에서 제품의 특성에 따라서 특별전담 조직이 만들어지기도 하는데, 이때의 조직은 점차 강해 지는 유통 환경의 압력에 대응하기 위해서 마 케팅-영업-연구소의 직원들로 구성되는 $\mathrm{TF}$ 가 주를 이룬다. 수집된 아이디어는 제품별 마케팅 담당자별로 정리되어 아이디어 풀을 구성하고 지속적으로 활용하며, 담당자 및 부서장급의 Gate Keeper를 통해 선정 및 정리된다. 제품 컨셉의 개발 단계에서는 해당 제품의 마케팅담 당자가 주축이 되어 충족되지 않은 소비자 니 즈를 충족시키는 컨셉을 개발하기 위한 여러 활동을 수행한다. 이때 요플레 글로벌 네트워크 내의 $\mathrm{TF}$ 를 통한 컨셉개발 방법론을 실제 활용 하게 되고, 이 외에도 이러한 컨셉을 후원하는 아이디어 및 시장 분석 자료를 함께 확인하게 되며, 특히 요구르트 형태별 전략과 상황에 맞
추어 진행한다. 이렇게 개발된 컨셉은 시장조사 를 통하여 정교하게 된다. 제품개발 및 시장조 사, 수익성분석 단계에서는 Gate Keeper를 통 과한 컨셉에 대하여 연구소, 디자인, 생산, 영업 등 전 부문을 고려한 제품 개발이 진행되고, 가 격 및 광고 커뮤니케이션 계획에 따라 자원을 배분하여 수익성 분석이 이루어진다. 이때에는 FGI(Focus Group Interview) 및 CLT (Central Location Test)를 비롯한 정성 및 정량조사가 2 차례 이상 수행되며, 해당 유관부서의 부서장급 이상 최고경영자에 이르는 Gate Keeper 들이 개발된 제품에 대한 조사결과를 바탕으로 평가 와 출시 여부를 결정하게 된다. 그리고 제품 출 시 및 사업부별 전략 단계에 이르러서는 광고 와 프로모션, 출시 후 전략에 대한 정교화와 세 분화가 수행되며, 각 유관부서에서는 마케팅 전 략에 따른 일정에 맞추어 마케팅 활동을 실행 하게 된다. 끝으로 제품 출시 후에는 영업을 비 롯한 전 부문에 걸쳐서 전사적으로 제품을 시 장에 안착시키기 위한 마케팅 활동을 수행한다. 이러한 절차를 통하여 제품이 출시되는 것이 빙그레의 일반적인 신제품개발 과정이다. 그러 나 급변하는 시장 환경에 대한 출시 시기 (timing)와 같은 속도의 문제가 발생하기에, 제 품의 성향과 전략적 상태에 따라서 중간 Gate Keeper 및 조사/분석 절차를 축소 또는 생략하 기도 한다.

\section{2 .2 빙그레의 신제품 개발을 위한 전략적 의사결정 방법}

시장에서의 경쟁 대응에 있어서 빙그레는 단 기적 안목보다는 중장기적 관점에서의 대응 논 
<그림 6> 전략캔버스 분석

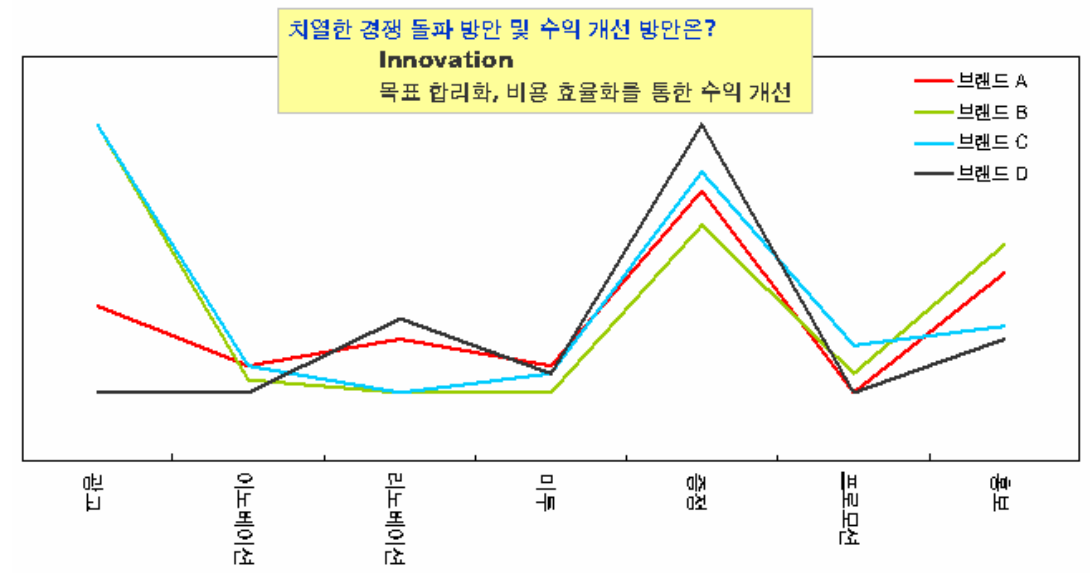

리에 따른 전략수립에 무게중심을 두고 있으며, 이를 위해 몇 가지 전략적 의사결정 방법을 활 용하고 있다.

우선, 전략캔버스(strategy canvas) 분석방법 을 들 수 있다. 전략 캔버스는 시장 경쟁을 이 루는 몇 가지 요소를 바탕으로 각 사별, 브랜드 별 행동 양식을 일정한 스케일로 분석한 후, 이 를 브랜드별 매출액을 반영한 가중평균을 구해 그래프화하여 각 사별 전략적 초점을 비교분석 해 보는 방법이다. 이를 통해 당사가 보완해야 할 요소나 핵심화해야 할 요소를 분명하게 설 명할 수 있다. 아래 그림은 2005년 드링킹 요구 르트시장에서 각사의 전략 배분 구도를 살펴보 기 위해 작성된 캔버스로, 빙그레는 이와 같은 의사결정 툴을 활용하여 각 사의 전략 구도를 파악하고 그 속에서 빙그레 만의 전략적 색깔 을 유지하기 위해 노력하고 있다.

두 번째는 로직트리(logic tree) 분석방법이다. 끊임없이 변화하므로 상황마다 그에 맞는 적절 한 마케팅 믹스 변경이 필요할 수 있기 때문에 아래와 같은 로직트리 분석을 통해 브랜드의
현 위치를 진단하고, 최적의 솔루션을 찾는 기 법을 활용하고 있다. 로직트리는 매킨지 컨설팅 에서 문제 해결을 위해 사용하는 방법으로, 빠 짐없이 중복되지 않게 문제 해결을 위한 요소 를 나열한 후 각각의 항목에 대해 평가단이 적 합성을 평가하여 최종적으로 솔루션을 찾는 방 법이다. 이러한 방법을 통해 임기응변적 전략 실행 시 나타날 수 있는 전략 간의 상충과 비 효율성 등을 사전에 제거할 수 있다는 장점이 있다.

세 번째 방법은 반응분석으로, 경쟁사의 가격 전쟁이 있을 경우, 이에 적절하게 대응하는 방 안을 강구하기 위한 의사결정방법이다. 반응분 석은 가격전쟁을 촉발한 경쟁사의 전략적 강도 (가로축)와 그에 대한 당사의 대응 비용(세로 축)을 기준으로 매트릭스를 활용하는 방법으로, 예를 들어 대응비용은 경쟁사와 동일한 가격 인하를 실시할 경우의 빙그레 손익 또는 무 대 응으로 일관할 경우의 매출 감소에 의한 손익 등을 확인하는 것이다.

빙그레는 이러한 방법을 활용하여 2005년에 


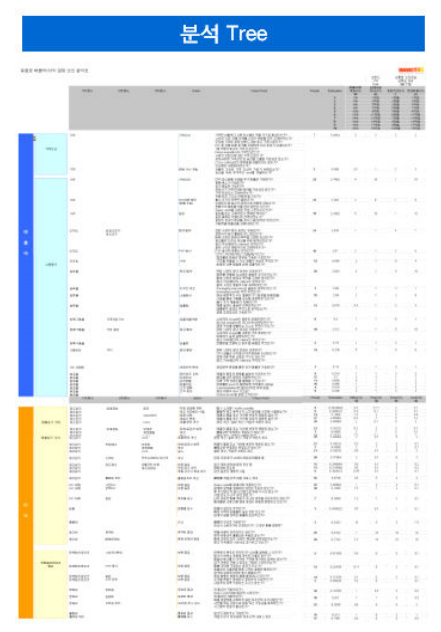

장보고라는 측면지원용 방패브랜드(flanker brand)를 출시하였으며, 다시 2005년 말 동일한 분석 방법을 통해 얻어진 결과를 토대로 장보 고를 장의힘으로 전환하는 의사결정을 하게 된 다. 빙그레가 처음 장보고를 도입할 시점인 2005년 3월에는 실질적으로 가격 전쟁과 같은 증정 행사가 각 사별로 강화되는 시점이었으며, 이때의 무반응 손실과 맞대응 손실을 비교해 본 결과, 맞대응에 대한 비용 타당성이 더 높은 것으로 나타났으며, 또한 증정행사를 촉발한 경 쟁사의 전략적 경쟁력은 크지 않은 상황이었다. 따라서 <그림 8>의 '방어전략'에 해당하는 의사 결정을 하고 닥터캡슐을 지켜내고 경쟁브랜드 들과 직접 경쟁하기 위한 목적으로 방패브랜드 인 장보고를 출시하였다. 그러나 6개월여 지난 시점에 와서는 전체 시장에서의 증정행사는 더 욱 일반적인 관행이 되어 맞대응에 투입되는 비용 수준은 크게 올라갔고, 이에 따라 빙그레 의 대응전략도 수정이 불가피하게 되었다. 이에 '수용전략'으로의 변화가 요구되었으며, 이러한

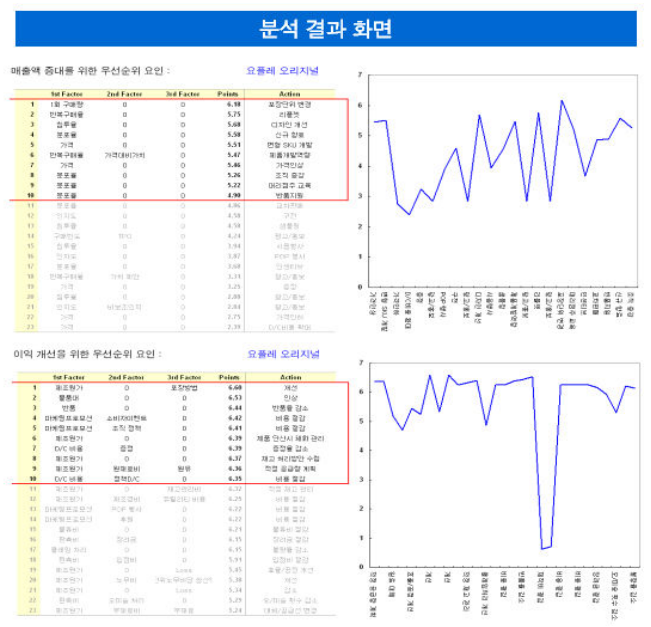

시장 환경의 변화를 수용하여 당사의 전략적 포지션을 변경시키는 결과물의 하나로 장보고 를 대체하는 장의힘을 출시하게 되었다.

\section{IV. 빙그레 요플레의 시장 선도적 신제품 마케팅전략}
4.1 시장 선도주자로서의 신제품 전략: 떠먹는 요구르트시장

\subsection{1 떠먹는 요구르트시장의 환경}

시판 브랜드들이 야쿠르트의 제품세분화 모델 을 그대로 수용하여 드링킹 요구르트에 집중하 면서 새로운 효능과 효과 발굴에 집중하는 과 정과 1990년대 중반에 나타난 떠먹는 요구르트 시장에서의 가격 전쟁이라는 두 가지 요인은 떠먹는 요구르트에 대한 소비자의 인식을 상당 


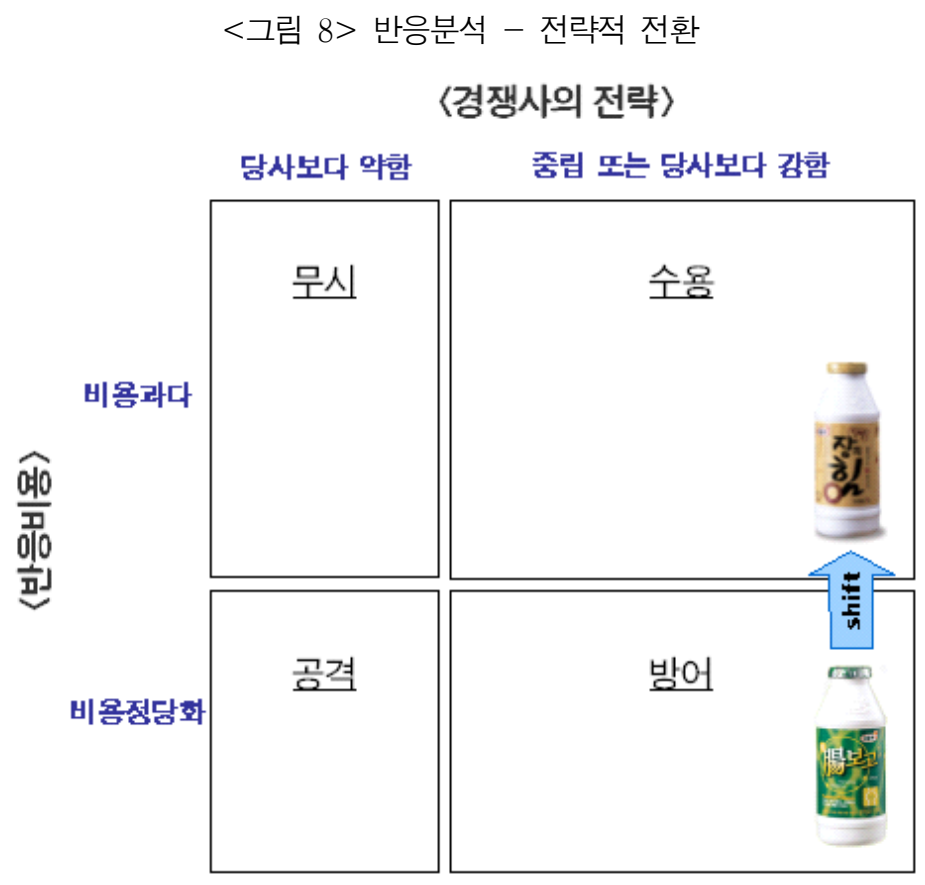

히 왜곡시키는 결과를 낳았다. 다시 말해, 떠먹

맛있는 간식 정도로 인식하게 되었다. 이는 아 는 요구르트나 드링킹 요구르트나 본체는 동일 래 <그림 $9>$ 의 떠먹는 요구르트 음용상황과 중 함에도 불구하고 다수의 소비자들은 드링킹 요 요 고려속성 조사결과에서도 확인할 수 있다. 구르트는 건강에 도움이 되는 기능성 제품으로 이러한 소비자들의 인식 때문에 서구 시장이 인식하는 반면, 떠먹는 요구르트는 몸에 유익한 떠먹는 요구르트를 중심으로 제품세분화가 진

<그림 9> 떠먹는 요구르트의 음용상황과 중요 고려속성
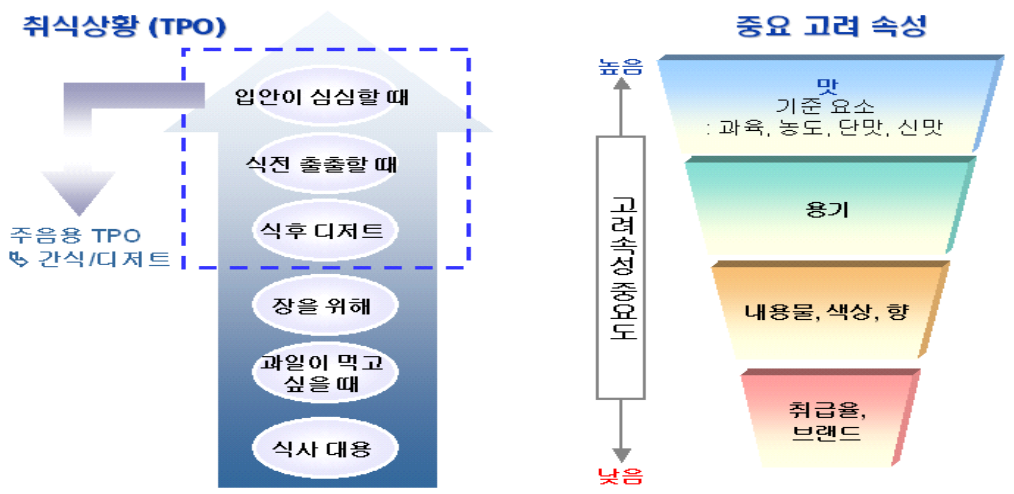

출처: 빙그레 자체 조사자료(2002년, 2004년) 
행되어 온 것과는 달리 국내에서의 떠먹는 요 구르트시장은 오랜 기간 정체된 것이 사실이다. 비록 최근에 와서 새로운 브랜드들이 시장에 선보이고, 또 그 중 일부는 사라지는 과정을 통 해서 90년대보다는 한 단계 발전된 분위기가 형성된 것은 사실이지만, 아직도 요플레 계열의 신규 브랜드를 제외하고는 광고 커뮤니케이션 이 전무한 실정이다. 이러한 커뮤니케이션의 부 재와 오랜 기간 동안의 시장 방치는 떠먹는 요 구르트시장에서의 다양한 세분화와 포지셔닝 기회를 활용하지 못하도록 만드는 가장 큰 걸림 돌이 되고 있다.

\section{1 .2 시장 선도적 신제품개발전략: '스위벨’과 '퓨엔'}

1) 떠먹는 요구르트제품의 마케팅전략 방향

5 개년 연속 떠먹는 요구르트 부분 브랜드파워 1위 - 최초인지도 $60.4 \%$, 비보조인지도 $91 \%$, 보조인지도 $99 \%$ 라는 막강한 인지도를 지닌 요 플레, 그러나 그 출발은 순탄치 않았다. 요플레 출시 이후 5 년 후에나 경쟁제품이 출시될 정도 로 너무나 앞서간 제품이었기에, 시장선점의 이 점보다는 '외롭게 시장을 만들어가는' 어려움이 더 컸다고 볼 수 있다. 1983년 최초 출시되었을 때는 사치품으로 분류되어 부가세 외에 특소세 가 붙어 400 원이라는 높은 가격이 형성되었고 (당시 시내버스 요금은 110 원), 그 특유의 풍미 가 일반 액상 요구르트에 익숙한 소비자 입맛 에 맞지 않아 초기에는 반품율도 상당히 높았 다. 이에 빙그레는 요플레 전담팀을 조직하여 표적시장을 상대로 $1: 1$ 마케팅을 전개하는 전 략을 통해 시장을 창출하고자 하였다. 가격에
대한 부담감이 적고, 프리미엄을 선호하며 유럽 풍 정통 요구르트 맛에 익숙한 소비자를 찾아 유행의 중심지였던 압구정동부터 공략하기 시 작하였다. 점차 요플레의 맛과 효용은 구전을 통해 전해졌고, 개방화의 큰 전환점인 88올림픽 을 계기로 시장 안착에 성공하면서 떠먹는 요 구르트라는 새로운 시장을 만들게 되었다. 그러 다가 90년대 말 드링킹 요구르트가 요구르트시 장을 주도하기 시작한 이후 자연히 떠먹는 요 구르트에 대한 시장관심은 작아졌고, 저가 제품 이라는 인식과 함께 별도의 마케팅커뮤니케이 션이나 제품세분화도 이루어지지 않은 채 과일 함유 떠먹는 요구르트가 떠먹는 요구르트시장 의 $84 \%$, 즉 대부분을 차지하면서 총 시장 규모 의 확대에 한계를 나타내고 있었다.

이 같은 떠먹는 요구르트시장의 전반적인 침 체와 저가 인식 등 어려운 시장상황에서 빙그 레는 보다 적극적인 마케팅전략이 필요하다고 판단하였다. 이를 위해 빙그레 요플레는 시장 선도자로서 떠먹는 요구르트 제품의 새로운 사 용법 개발·전파 및 제휴업체와의 공동마케팅 을 통한 새로운 시장기회 모색과 같은 '시장개 발'의 전략적 방향과 함께 시장기회가 있는 신 규시장을 찾아 소비자들의 충족되지 못한 욕구 를 충족시켜줄 수 있는 새로운 시장을 찾아내 는 보다 적극적인 '다각화 전략'을 구사하기로 하였다. 이러한 전략방향은 증정행사, 가격할인 과 같은 시장침투전략이나 기존시장을 대상으 로 기존제품에 새로운 향료, 성분추가, 패키지 방식 변화 등의 소극적인 제품개발 전략으로는 떠먹는 요구르트시장을 확대하는데 한계가 있 다는 판단을 토대로, 즉 시장의 선도주자로서 시장자체를 키우기 위한 전략적인 의사결정으 


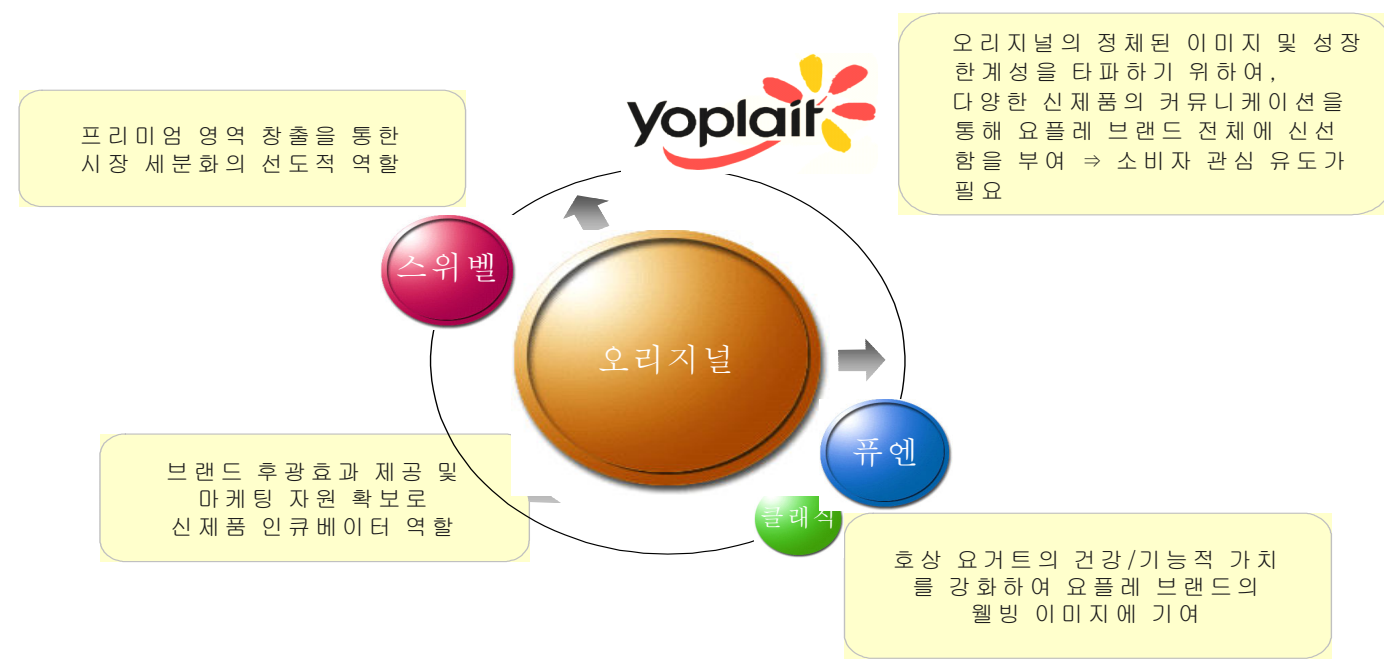

로 해석할 수 있다.

이에 요플레는 2003년 프리미엄 제품과 기능 성 제품 2종에 대한 시장테스트를 실시한 후, 2004년 8월 프리미엄 요구르트 '스위벨'을 출시 하며 떠먹는 요구르트시장에서 10년 만에 광고 커뮤니케이션을 재개하였고, 2006년 6월에는 건 강지향 순수 요구르트 '퓨엔’을 출시하였다 $<$ 그 림 $10>$ 참조).

2) 떠먹는 요구르트의 신제품개발 전략

이제 앞서 언급한 신제품 스위벨과 퓨엔이 어 떻게 개발되었는지를 보다 자세히 살펴보기로 하자.

떠먹는 요구르트는 오랜 기간 가격이 저렴한 저관여 제품으로 여겨지며 '요플레 = 떠먹는 요구르트의 대명사 = 저가' 라는 인식이 고착 되었다. 이에 요플레의 브랜드 자산가치를 활용 하고자 하는 패밀리브랜드 전략의 구사에는 상 당한 제약이 있었다. 이러한 상황에서 요플레가
설정한 신제품 마케팅의 방향은 (1) 저가의 이 미지에서 탈피하고 (2) 요플레 오리지널과의 자 기시장 잠식효과를 최소화하며 (3) 신규수요 창 출이 가능한 시장이어야 했다. 빙그레는 이 같 은 신제품 마케팅전략의 방향을 충족시켜줄 수 있는 신제품을 개발하고자 노력하였으며, 그 결 과 스위벨과 퓨엔이라는 2 개의 새로운 신제품 을 출시할 수 있었다.

<그림 $11>$ 간식시장에 대한 소비자인식

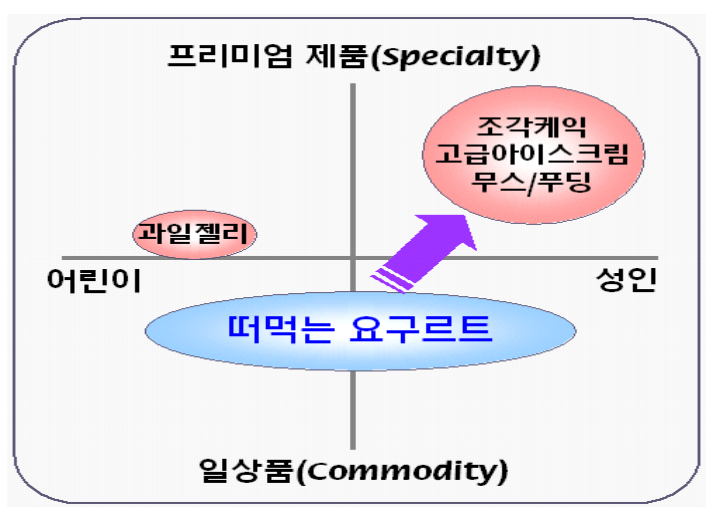


<그림 11>을 보면, 소비자들의 인식 상에서 프리미엄 간식 영역은 기존 떠먹는 요구르트에 대한 인식과는 확연히 구분되는 다른 시장이었 다. 이 시장으로의 접근을 시도한 2004년 신제 품이 '프리미엄 요거트 - 스위벨'이고 이는 기 존 떠먹는 요구르트에 대한 미충족 옥구를 해 결함으로써 새로운 표적시장과 떠먹는 요구르 트의 음용상황을 확대함으로써 신규수요를 창 출한 제품으로 평가받고 있다(<그림 12> 참조).

2006년 신제품인 '퓨엔'은 웰빙 트렌드의 영향 으로 플레인 제품에 대한 관심이 커지는 시점 에, 과일 요구르트의 단맛과 플레인 요구르트의 심심한 맛 사이에서의 갈등, 과일조각의 씹히는 느낌에 대한 선호와 비선호, 집에서 만든 요구 르트처럼 첨가성분을 최소화한 순수한 느낌에 대한 니즈 등 기존 제품에 대한 소비자의 미충 족 옥구와 해외 트렌드를 접목하여 출시된 제 품이다. 외국의 떠먹는 요구르트시장에서 판매 되는 플레인 제품과는 달리 국내 소비자는 과 일조각이 없는 부드러운 맛을 내는 떠먹는 요
구르트를 총칭하여 플레인 형태로 구분하는 경 향이 있는데, 이는 떠먹는 요구르트에 들어있는 과일조각에 대한 소비자 선호가 양분되기 때문 으로 해석할 수 있다. 이 같은 시장상황을 토대 로 기존 요플레 오리지널로 대변되는 일반 과 일제품과는 다른 표적마케팅 전략을 통해 추가 적인 매출을 창출할 수 있을 것으로 보고 웰빙 트렌드에 따라 떠먹는 요구르트에도 구매 고려 속성의 중요한 차원인 건강/기능적 가치를 부 여하기 위하여 "pure \& natural"이라는 컨셉을 접목한 것이 '건강지향 순수 요거트 - 퓨엔’이 며, 이는 떠먹는 요구르트시장에 새로운 세분시 장을 형성하며 총 시장의 확대를 가져올 것으 로 기대된다.

이렇게 시장의 관심을 떠먹는 요구르트 카테 고리로 재유인함에 따라 타사에서도 신제품을 출시하며 떠먹는 요구르트시장은 다시 활성화 되기 시작하였다. 특히 요플레 출시 초기에 표 적시장 $1: 1$ 마케팅을 진행하였던 것처럼, 강남 지역 유명 레스토랑에서 요플레를 활용한 메뉴

\section{<그림 $12>$ 스위벨 소비자조사 결과}

[기존 떠먹는 요구르트에서의 미충족 욕구]

-제품/용기의 이미지가 가정용이라서 밖에 서 먹기에는 다소 부적합

-농도가 묽어서 잘 흘러내리기 때문에 스 푼으로 떠서 깔끔하게 먹는 것이 어려움

-발효유 특유의 텁텁한 맛이 있어서 산뜻 하고 가벼운 느낌은 약함

$\rightarrow$ 저가의 평범한 간식 or 식사 대용
[스위벨에 대한 만족]

-용기가 이뻐서 회사나 밖에서 먹어도 괜 찮고 손님 접대용으로도 좋을 것 같아요

•농도가 흐르지 않아 깨끗하게 먹기 편하 고, 부드러우면서도 탱글탱글한 느낌이 새롭게 느껴져요

-먹고 난 뒤 뒷맛이 남지 않고 산뜻해요 새로운 느낌의 프리미엄 간식

패키지/농도/향료 등에서 기존 떠먹는 요구르트가 지닌 약점이 보완되어, 향후 스위벨을 통해 새로운 음용상황 확대가 기대됨

<출처> 빙그레 자체 조사자료(2004) 
를 개발, 판매하는 등 공동마케팅을 통해 특정 고객층의 신제품에 대한 관여도 제고와 요구르 트 사용 확산을 통한 전체 시장 확대에도 노력 을 기울이고 있다. 이 같은 떠먹는 요구르트시 장에서의 마케팅노력에 힘입어, 일반 과일요구 르트 외에 프리미엄과 과육미포함(플레인 및 과즙함유) 요구르트 제품시장이 $20 \%$ 수준까지 확대되었고, 이들 제품시장의 높은 신장세 $(37.7 \%)$ 로 인해 2006년 상반기 기준 떠먹는 요 구르트의 총 시장도 $8.5 \%$ 의 양호한 신장세를 보이고 있으며, 시장지배력도 점점 강화되어 떠 먹는 요구르트시장에서 $41.2 \%$ 의 시장점유율을 나타내고 있다. 이 같은 결과는 떠먹는 요구르 트시장의 선도자로서 신규시장을 개척하는 등 전체 시장 자체를 확대하기 위한 빙그레 요플 레의 선도적 신제품 마케팅전략이 있었기에 가 능했다고 볼 수 있다.

\section{2 시장 후발주자로서의 신제품 전략: 드링킹 요구르트시장}

\section{2 .1 드링킹 요구르트시장의 환경}

드링킹 요구르트의 시장 환경은 크게 두 가지 측면에서 살펴볼 수 있는데, 첫째는 방판중심의 야쿠르트가 만들어놓은 약처럼 인지되는 기능 성 드링킹 요구르트의 성공 이후 드링킹 요구 르트가 갖는 위상과 잠재력에 대한 착시 효과 에 따른 시판시장의 기능성 요구르트제품 개발 붐(boom), 둘째는 선도주자인 남양유업 불가리 스의 가격인상 이후 촉발된 후발업체들의 과도 한 가격할인전쟁에 따른 드링킹 요구르트시장 의 수익성 악화를 들 수 있다.
우선, 첫 번째 드링킹 요구르트시장의 환경에 대해서 살펴보기로 하자. 1995년 본격적으로 기 능성 드링킹 요구르트시장에 뛰어든 야쿠르트 는 메치니코프의 성공에 힘입어 2000년에 국내 요구르트시장의 한 획을 긋는 신제품 드링킹 요구르트를 출시하는데, 바로 '헬리코박터 프로 젝트 윌' 이다. 식품의 효능/효과 홍보가 법적 으로 금지된 국내 시장에서 야쿠르트는 이와 같은 창조적인 브랜드명과 관련 과학자를 모델 로 하여 막대한 광고비를 집행한 결과, 이 제품 을 단숨에 1,000 억 원이 넘는 대형브랜드로 정 착시켰다. 이 후 시판 시장에서는 남양유업과 매일유업이 각각 위력과 구트라는 이름으로 후 발제품을 출시하는 등 거의 대부분의 요구르트 회사들이 야쿠르트 윌의 모방제품을 출시하였 다. 그러나 모방제품으로서의 차별화 실패와 공 중파를 이용한 광고 전략의 한계로 인해 이들 제품은 시장에서 빠르게 사라졌거나 겨우 명맥 만 유지하는 정도의 매출 규모를 보이고 있다.

이 과정에서 나타난 중요한 현상의 하나로 요 구르트 총 시장에서 드링킹 요구르트가 갖는 위상과 잠재력에 대한 착시 효과를 들 수 있다. 시판 시장에서 드링킹 요구르트의 잠재 수요 규모는 수년간 큰 변화가 없었음에도 불구하고, 야쿠르트의 방판 시장에서의 제품 정착은 시판 시장에 참여한 회사들에게까지도 드링킹 요구 르트의 성장성을 과대평가하게 만들었고, 이러 한 시판 브랜드들의 판단 오류는 매일유업의 구트 $\mathrm{HD}-1$, 서울우유의 헤파스 같은 기능성 드 링킹 요구르트 제품들의 출시로 이어졌다. 이들 제품은 미미한 판매 실적을 보이다가 일부 제 품의 경우 시장에서 조기에 철수하기도 하였으 며, 이외에도 2005 년에 출시된 남양유업의 프로 
젝트 120 80과 프로젝트 닥터인슈는 각각 혈압 과 당뇨병에 도움을 주는 제품들로 개발되었으 나 시장에서 큰 반향을 얻지는 못하고 있는 상 황이다.

이처럼 방판과 시판시장의 성과 간에는 왜 현 격한 격차가 발생하는 것일까? 이에 대해서는 야쿠르트가 만들어놓은 '약처럼 인지되는' 요구 르트로서의 포지셔닝과 법적 규제 사이에서의 불일치에서 그 원인을 찾을 수 있다. 국내에서 는 법적으로 식품의 효능/효과 홍보를 엄격히 제한하고 있다(여러 국가에서 정도의 차이는 있으나 약으로 오인될 수 있는 내용의 홍보는 금하고 있음). 이러한 제한은 제품명, 제품 포 장에 표기된 내용, 리플렛, 웹, 광고 등 기업의 마케팅 홍보활동의 거의 전반에 걸쳐 적용되고 있다. 따라서 위, 간, 당뇨, 혈압 등에 효과가 있는 요구르트를 개발했다 하더라도 이들 제품 의 효과와 그 효과를 뒷받침하는 설득 요소를 소비자들에게 풀어서 설명하기란 결코 쉬운 일 이 아니다. 더군다나 그렇게 다양한 효능/효과 를 소비자들의 인지 속에 정확하게 포지셔닝 한다는 것은 더욱 더 난제일 수밖에 없다.

그렇다면 야쿠르트는 어떻게 위와 간으로 이 어지는 신제품을 연이어 성공시킨 것일까? 야 쿠르트의 성공 요인을 살펴보면 (1)기능성 제품 전문가로서의 야쿠르트의 기업 이미지, (2)소위 '야쿠르트 아줌마'로 표현되는 막강한 대인 판 매채널을 통한 설득 효과, (3)엄청난 물량의 광 고 집행, (4)학계와 연결된 네트워크, (5)국내 유 업체로는 유일하게 유산균주 개발 전문 인력 보유 등을 들 수 있겠다. 물론, 장 $\rightarrow$ 위 $\rightarrow$ 간 으로 이어지는 기능적 세분화 전략 및 이에 부 합하는 마케팅 자원 배분 등의 질적 요소는 분
명히 긍정적으로 평가되어야 할 것이다. 반면, 야쿠르트가 자사의 강점을 적절히 활용하여 개 척한 방판 시장에서의 세분화 모델을 시판 브 랜드들이 그대로 수용하면서 엄청난 마케팅 자 원의 투입에도 불구하고 소비자의 인지 속에서 는 명확한 개념 정립이 되지 않았을 뿐만 아니 라, 야쿠르트와는 다른 방향에서 요구르트의 본 질에 충실한 시장기회를 놓치게 되었다고 볼 수 있다.

두 번째 드링킹 요구르트시장의 환경에 대해 서 살펴보기로 하자. 2003년 4월에 남양유업은 불가리스 프라임을 새롭게 선보이면서 기존의 불가리스가 할인점 기준 4 개들이 1 팩에 2,600원 에 판매된 반면 3,400 원이라는 매우 높은 가격 대로 진입하였다. 남양유업은 몇 개월간의 테스 트 마케팅을 거쳐 2004년 5월에 불가리스의 모 든 제품라인을 프라임으로 대체하는 결정을 하 게 된다. 할인점 기준으로 $31 \%$ 의 가격 인상이 라는 매우 이례적인 결정을 단행한 것이다. 시 판 드링킹 요구르트시장에서 부동의 1 위인 남 양유업의 이와 같은 결정은 시장의 성숙 과정 에 매우 중요한 변곡점으로 작용하였다. 즉, 1 위 브랜드의 큰 폭의 가격 인상이 후발업체들 에게는 시장 진입의 기회 요인을 제공한 것이 다(<표 $4>$ 참조).

위의 표에서 알 수 있듯이, 기존의 좁은 가격 범위에서는 시장 침투가 쉽지 않았지만, 불가리 스 프라임이 형성한 고가의 가격대는 후발업체 들에게 가격을 전략적으로 활용할 수 있도록 만들었다. 기존의 $1 \sim 2$ 위 시판 브랜드인 불가리 스와 닥터캡슐은 매출 대비 대략 두 자릿수의 광고비를 집행하고 있었는데, 새로운 가격에서 는 후발업체들도 강력한 촉진전략을 시행할 수 
<표 4> 드링킹 요구르트제품의 판매가격 변화

(단위: 할인점 기준 판매가/팩)

\begin{tabular}{|c|c|c|}
\hline & 2004년 5월 이전 & 2004년 5월 이후 \\
\hline 불가리스 & 2,600 원 & 3,400 원 \\
\hline 닥터캡슐 & 2,400 원 & $2,400 \rightarrow 3,000$ 원 \\
\hline 장에는 $\mathrm{GG} \rightarrow$ Probio GG & $2,000 \sim 2,200$ 원 & 3,000 원 \\
\hline 비피더스 & & 2,800 원 \\
\hline
\end{tabular}

있는 가격대를 찾게 된 것이다. 이에 후발기업 인 매일유업은 장에는 $\mathrm{GG}$ 를 프로바이오 $\mathrm{GG}$ 로 리뉴얼하면서 $4+2$ 증정행사로 당시로서는 파격 에 가까운 판촉을 단행하였고, 뒤이어 롯데햄우 유도 비피더스 요구르트로 $1+1$ 행사를 시행하 기에 이르렀다. 이렇게 촉발된 가격 전쟁은 불 가리스 이외의 여타 브랜드들에도 파급되었으 며 이후, 거의 상시 $1+1$ 증정이라는 전무후무 한 판촉수단이 자리 잡게 되었다. 현재도 할인 점 매대에서는 언제든 $1+1$ 판촉을 진행하는 브 랜드를 찾을 수 있게 되었는데, 이러한 증정행 사의 상시화는 결과적으로 드링킹 요구르트시 장 전체의 판매가격을 2004 년 5월 이전보다 오 히려 떨어뜨리는 효과를 초래하였다. 이 같은 드링킹 요구르트시장의 경쟁상황은 첫째, 드링 킹 요구르트시장의 수익성을 크게 악화시켰으 며, 둘째, 시장 성장의 핵심요인을 광고 등의 커뮤니케이션을 통한 풀(pull)전략에서 가격할 인에 의한 판촉 등 푸쉬(push)전략으로 변화시 켰다. 이러한 변화는 향후 드링킹 요구르트시장 의 질적 성장과 새로운 시장기회의 창출에도 커다란 장애물로 작용할 것으로 예상된다.
4.2 .2 차별적 포지셔닝에 의한 신제품개발 전략: '닥터캡슐'과 '5색5感”

드링킹 요구르트시장의 경쟁상황에서 후발주 자인 빙그레는 소비자에게 새로운 가치를 제공 하는 차별화전략을 실시하기로 결정하였다. 즉, 야쿠르트의 세분화 모델에 편승하기 보다는 소 비자에게 빙그레만의 차별적인 가치 컨셉의 제 안을 통해 독자적인 영역을 구축하고 더 나아 가 드링킹 요구르트시장에서의 새로운 시장패 러다임을 창출하고자 하는 적극적인 차별화전 략이라 볼 수 있다. 이 같은 전략방향은 후발주 자에게 적합한 전략으로 Hauser and Shugan (1983)이 제시한 경쟁자들의 부정확한 포지셔 닝을 찾아 소비자 선호를 학습시키는 전략과 Carpenter and Nakamoto(1989)가 제시한 소비 자에게 어떤 가치있는 것을 제공하는 차별화전 략과 맥을 같이 한다고 볼 수 있다. 다음에서는 후발주자인 빙그레의 차별화 마케팅전략을 토 대로 시장에 출시된 '닥터캡슐'과 '5색5⿱⿵⿰丿⿺⿻⿻一㇂㇒丶⿱一口心'” 의 신 제품 개발전략에 대해서 살펴보기로 하자.

1) 신제품 닥터캡슐의 차별화전략

현재 시판 시장에서 2 위 브랜드로 자리매김하 고 있는 닥터캡슐은 1997년 4월에 출시되었다. 
1990년에 불가리스, 1995년에 메치니코프가 이 미 출시되었던 것을 감안하면 후발 브랜드가 정착하여 10 여년이 지난 오늘날까지 2 위로 자 리매김하고 있다는 사실은 결코 흔하지 않은 경우라고 할 수 있다. 그 비결은 닥터캡슐이 제 시한 혁신적 컨셉 -위산을 통과하면서 쉽게 죽는 유산균을 캡슐로 둘러싸서 보호한다는 에 있다. 닥터캡슐이 출시되기 전까지 업체들의 주요 관심사는 유산균의 수였다. 예를 들어, 더 많은 유산균이 함유된 ' $\bigcirc \bigcirc$ 요구르트' 같은 형 식의 홍보 문구가 자주 사용되던 시절이었다. 그러나 대부분의 유산균이 강한 산성의 위액을 만나면 죽어버린 다는 점을 감안하면 ${ }^{2)}$ 제품에 포함된 유산균 수 자체는 큰 의미가 없다고 할 수 있다. 빙그레는 이러한 사실에 착안하여 유 산균의 체내 생존력을 높이는 새로운 기술을 탐색하기 시작하였고, 요플레의 세계적 네트워 크가 보유하고 있는 정보력과 노하우를 바탕으 로 마침내 닥터캡슐을 출시하게 된 것이다. 닥 터캡슐에 적용된 캡슐이 일부 경쟁업체들의 유
사 캡슐 제품과는 그 구조에서 확연한 차이를 드러낸다. 타사의 캡슐은 주로 스프레이 코팅 방식에 의한 것으로 캡슐 당 존재하는 유산균 의 수가 매우 작으며, 크기도 아주 작아 육안으 로는 잘 식별이 안 되는 분말 형태이다. 반면, 닥터캡슐의 캡슐은 2 중으로 둘러싼 직경 $1.5 \mathrm{~mm}$ 의 구조물로 상당한 수의 유산균을 내포하고 있다(<그림 13> 참조).

이러한 캡슐을 적용한 요구르트제품 생산기술 은 한국뿐만 아니라 미국, 대만, 홍콩, 싱가폴에 서도 특허 기술로 인정되었다. 귀여운 캡슐 캐 릭터 및 "랄랄라라라 "로 기억되는 징글 사운 드를 동원하여 ”유산균이 살아서 장까지"를 시 종일관 제시하여 대한민국 국민이라면 누구나 떠올리는 문구가 되었으며 징글 사운드는 어린 아이까지도 따라 부르는 유행가가 되기도 하였 다. 2003년부터는 기존의 광고와는 방향을 다소 바꾸어 장까지 살아서 간 유산균의 활약을 단 계적으로 표현하는 데 집중하였다. 남녀노소 누 구나 좋아하는 젊은 배우, 차태현을 광고 모델

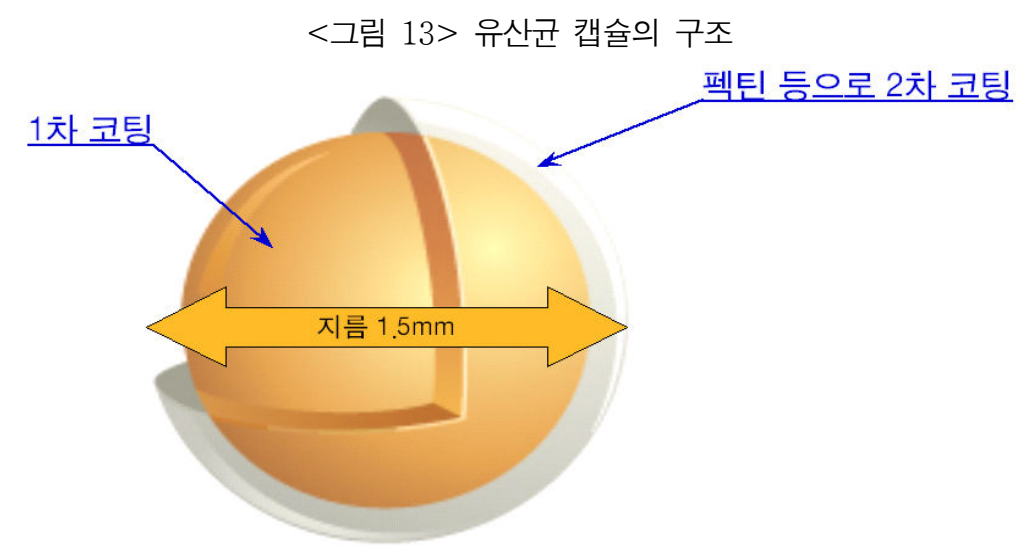

2) 위의 $\mathrm{pH}$ 는 1 2로 위가 완전히 비워지는 것은 식후 약 4 시간 정도이며, $\mathrm{pH} 4$ 이하에서 일반적인 세균들이 30 분 이내에 $99.9 \%$ 가 죽게 되며 $\mathrm{pH} 3$ 이하의 정상 위에서는 15 분 이내에 $99 \%$ 의 미생물이 감소하고 1 시간 뒤에는 살아있는 미생물을 거의 찾아볼 수 없게 된다. 
로 하여 1 차 캠페인에서는 "젊은 장을 위하여" 라는 새로운 슬로건을 제시하였고, 2004년 1월 부터 방영된 2 차 캠페인에서는 "젊은 장 $=$ 리 듬있게 움직이는 장”으로 규정하여, 보다 구체 적으로 캡슐 유산균의 효능을 보여주고자 하였 다. 이러한 마케팅 전략의 변경은 그대로 적중 하여 전체 시장이 다소 주춤하던 2003년에도 닥터캡슐은 1 차 캠페인 시작 이후 $20 \%$ 대의 높 은 성장률을 기록하며 도약하였다. 출시 후 만 7년째로 접어드는 지금도 닥터캡슐은 자타가 공인하는 농후 요구르트의 대형 브랜드로 성장 하였으며, 2004년에는 소비자가 기준 530억 원 수준의 매출 실적을 올렸으며, 하루 판매 수량 만도 20 25만병에 달한 바 있다.

닥터캡슐의 마케팅전략은 다른 경쟁기업의 마 케팅 전략에도 많은 변화를 주었는데 무엇보다 도 가장 큰 변화는 유산균 수에 관한 논쟁의 종식일 것이다. 함유된 유산균 수로 요구르트를 구분 짓던 관행은 닥터캡슐이 출시된 이후 자 취를 감추었다. 이 같은 빙그레 닥터캡슐의 신 제품전략은 기존의 경쟁사들이 유산균 숫자중
심의 경쟁에서 소비자가 마시기 전의 유산균 숫자가 아니라 장까지 도달한 유산균 숫자가 중요한 것이라는 사실을 확인시켜주는, 즉 경쟁 사들의 부정확한 포지셔닝을 찾고, 소비자에게 새로운 가치기준을 제시하고 이를 소비자들에 게 학습시키는 일련의 차별화전략을 실시했다 는 데서 성공의 요인을 찾을 수 있을 것이다.

2) 신제품 5 색5感의 차별화전략

앞서 국내 드링킹 요구르트시장의 환경에서 살펴본 바와 같이 국내 드링킹 요구르트시장은 불가리스의 가격인상이 본격화된 2004년을 분 기점으로 하여 커다란 변화를 격게 된다. 후발 업체들의 시장 진입과 함께 이들이 중심이 된 증정행사로 인한 가격할인 전쟁과 이에 따른 기존 브랜드의 수익성 악화와 함께 드링킹 요 구르트시장의 마케팅 동력이 풀전략에서 푸쉬 전략으로 변경되는 양상을 보이게 되었다. 이 같은 현상은 풀전략을 실시한 대표 브랜드와 푸 쉬전략을 실시한 대표 브랜드의 2004년 1월 이후 판매 변화에서도 알 수 있다(<그림 14> 참조).

\section{<그림 14> 드링킹 요구르트시장의 판매 추이}

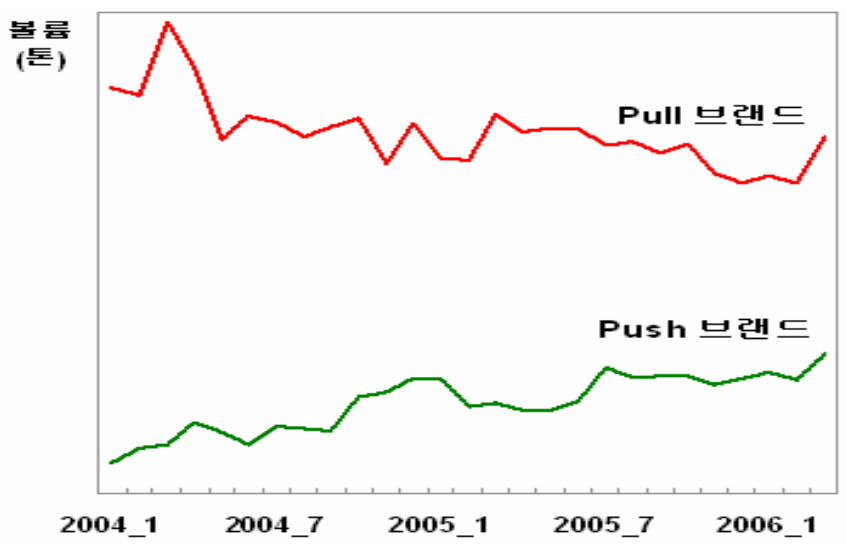


증정행사 등 판촉위주의 푸쉬전략을 실시한 브랜드의 급격한 매출 증가는 주로 풀전략을 취하던 기존 브랜드를 잠식하는 모습으로 나 타났다.

이러한 상황에서 2 위 브랜드인 닥터캡슐은 기 로에 놓이게 되었다. 공격적 커뮤니케이션을 통 한 비용 회수는 점점 더 어려워지는 시장 환경 에서 증정행사 브랜드에 맞대응하는 것은 자칫 10 여 년간 쌓아온 브랜드의 위치를 한순간에 저 가이미지의 제품으로 전락시킬 수 있기 때문이 다. 앞서 빙그레의 신제품 개발을 위한 전략적 의사결정 툴에서 제시했던 반응분석과 로직트리 분석을 통해 공통적으로 도출된 빙그레의 과제 는 신제품 개발의 필요성과 기존제품의 비용관 리로, 특히 혁신적인 신규 브랜드의 출시를 통 한 드링킹 요구르트시장의 영역 확대를 시도할 필요성이 제기되었다. 이렇게 해서 2006년에 신 제품 5 색5感이 출시되었으며, 다음에서는 5 색5
感의 신제품개발 과정과 후발주자로서 기존 드 링킹 요구르트시장의 패러다임을 전환시키기 위 한 빙그레의 신제품 차별화 전략에 대해서 살펴 보기로 한다.

(1) 신제품 개발 1 단계

빙그레의 신제품 개발과정인 Stage \& Gate 프로세스에 따라 아이디어 수립에 들어간 빙 그레는 드링킹 요구르트시장을 새로운 각도에 서 바라보는 프로젝트를 시작하였다. 야쿠르트 가 주도하는 드링킹 요구르트시장의 세분화 모델에서 과감하게 벗어나보자는 취지였다. 아 래 <그림 $15>$ 와 같이 드링킹 요구르트시장의 어려움과 요플레의 강점을 고려하면서 소비자 들의 드링킹 요구르트 음용동기를 검토한 결 과, 빙그레 요플레는 두 가지의 신제품 개발 핵심 컨셉으로 '자연(naturalness)'과 '과일의 기능(fruit functionality)'를 도출할 수 있었다.

\section{<그림 15> 드링킹 요구르트시장의 환경과 음용이유}

기존 드링킹 요구르트는 너무 어렵다 $\rightarrow$ 커뮤니케이션의 법적 제약 $\rightarrow$ 임상 데이터 확보의 어려움

(ㅇ) 위, 간, 혈압, 당뇨.. 시판 시장의 규모도 작고, 효능에 대한 신뢰감을 전해주기도 어려운데.

(ㅇ) 일상에서 소비자들이 접할 수 있는 친근한 정보의 수준에서 찾을 수 있는 아이디어는 없을까?

(2) 요즘 단맛과 가공 식품의 첨가물에 대한 소비자들의 우려도 점점 커지고 있고.

()ㅏ시장 1 위 요플레 - 우리만의 강점은 "과일" 인데

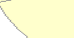

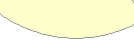

출처: 빙그레 자체 조사자료(2004)

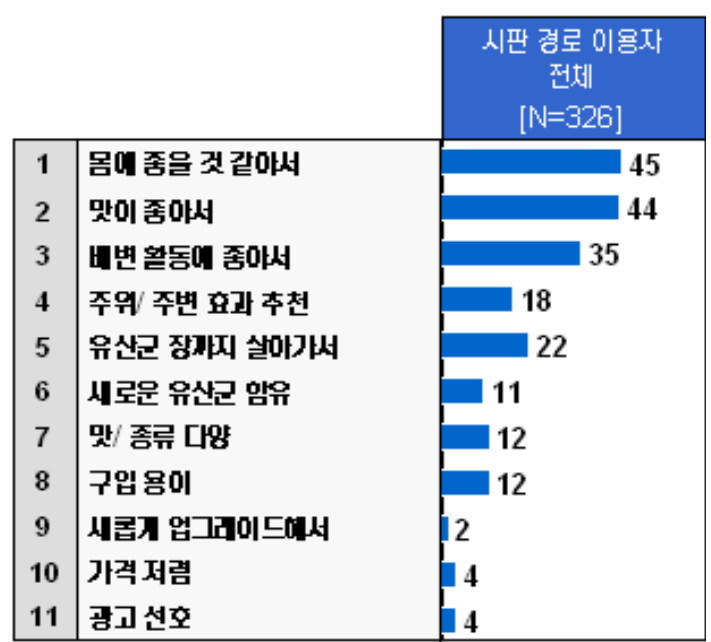

시판 경로 이용자

$[N=326]$

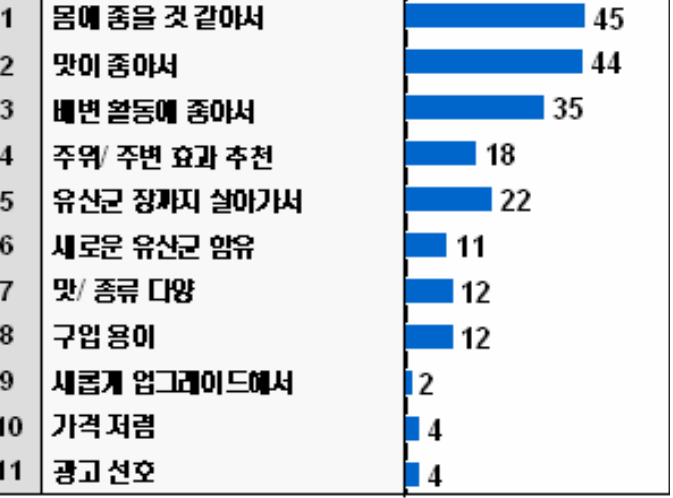


(2) 신제품 개발 2 단계

과일의 기능성(fruit functionality)에 주목하 는 현상은 해외에서도 오래전부터 전개되어 온 건강 트렌드의 하나라고 볼 수 있다. 미국에서 는 1988년 암학회가 처음 제창한 이래 ‘5 a day the color way'라는 캠페인을 시행하고 있 으며, 싱가폴에서도 'Know your colors'라는 슬 로건 하에 초등학교에서는 매주 금요일을 과일 을 먹는 날로 정하고 있다. 국내에서는 $\mathrm{KBS}$ 생로병사의 비밀에서 컬러과일 건강법이 다루 어진 이후부터 다양한 방송프로그램을 통해 관 련 내용들이 소개되고 있다. 과일의 색깔이 중 요한 이유는 파이토케미칼이라는 성분 때문으 로, 파이토케미컬은 종류에 따라 체내에서 항암 작용, 항산화 작용, 노화 방지, 면역력 증강 등 의 역할을 하는 것으로 알려져 있으며, 꾸준히 섭취할 경우 건강관리에 큰 도움이 될 수 있다.
빨간색 과일은 암을 예방하는 데 좋고, 노란색 과일은 혈관계 질환예방에, 그리고 보라색 과일 은 불로장생의 묘약으로 일컬어지기도 한다. 또 한 컬러 자체가 나타내는 컬러테라피 효과에 따라 일상생활에서 신체 상태에 따라 각각 다 른 색의 과채류를 섭취하면 기분 전환에도 도 움이 된다. 예를 들어, 입맛이 없고 무기력할 때는 빨간색 과채류를, 우울하고 신경이 예민할 때는 노란색 과일을, 정신적 스트레스로 몸과 마음이 지칠 때는 녹색 과채류를 섭취하면 좋 다. 빙그레는 색깔과일 건강법이라는 요구르트 에서의 새로운 가치 제안을 좀 더 확고히 하기 위하여 여기에 '자연(naturalness)'의 컨셉을 함 께 고려함으로써 설탕, 합성 색소, 합성향, 보존 료 등을 사용하지 않고 제품을 완성하고자 하 였다(<그림 $16>$ 참조). 이러한 도전은 매우 어 려운 과제였는데, 이에 대해 빙그레 마케팅실

\section{<그림 16>5색5感의 제품 컨셉}

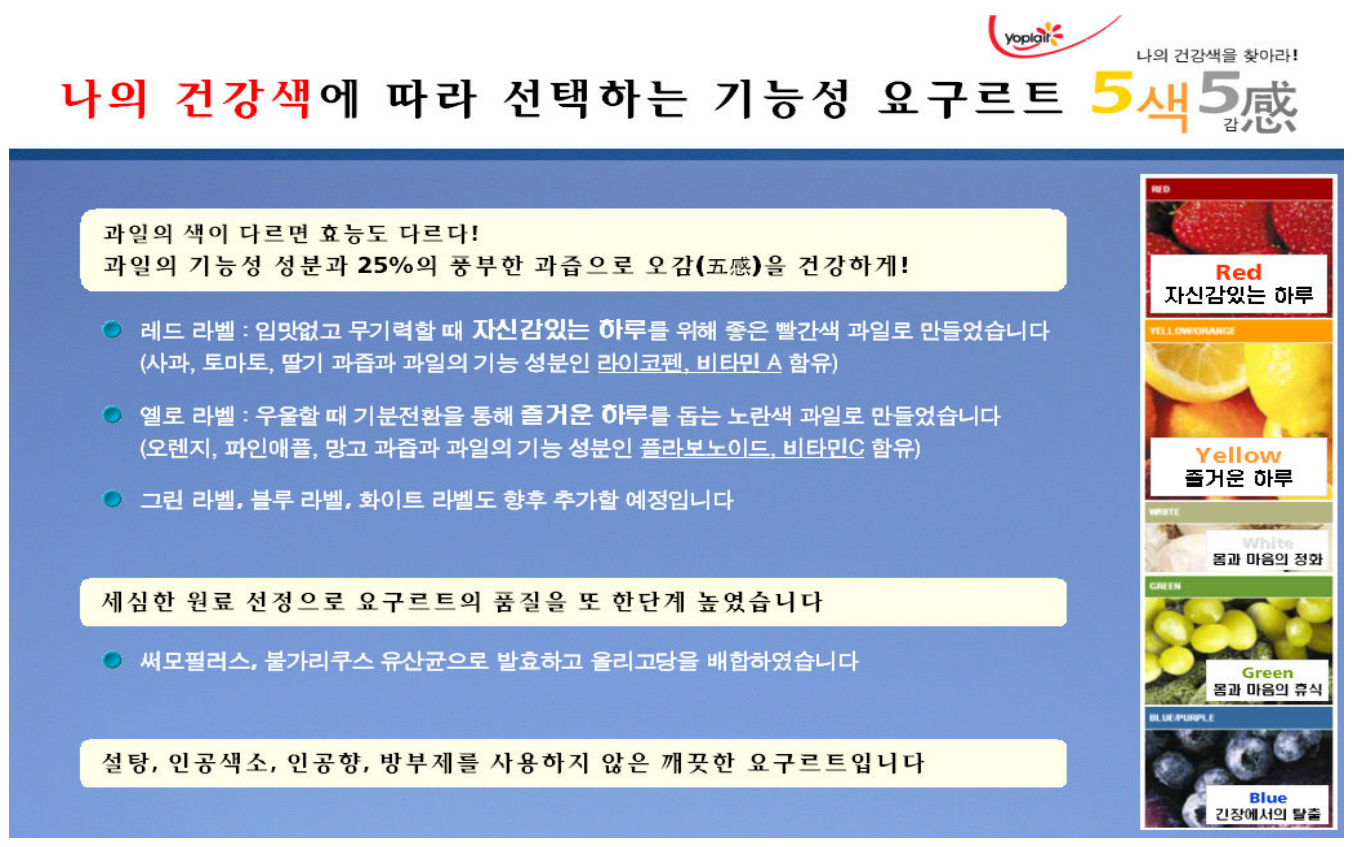

182 한국마케팅저널 제8권 제 3 호 2006년 10 월 
관계자는 다음과 같이 애기하였다. "우리가 흔 히 먹어오던 과일 맛의 요구르트는 적당한 양 의 설탕과 합성 착향료가 만들어낸 것으로(물 론, 과즙도 일부 들어간다), 여기에 길들여진 우리의 입맛으로 맛본 첫 시제품은 매우 실망 스러운 수준이었다. 마치, 요리 견습생이 끓인 조미료를 전혀 사용하지 않은 된장찌개의 허전 하고 밋밋한 맛과 같다고 해야 할까?"

\section{(3) 신제품 개발 3 단계}

$\mathrm{R} \& \mathrm{D}$, 마케팅, 원료 공급업자가 긴급회의를 가진 후 도출한 해법은 3 가지 과일의 종류와 혼합비율의 반복조정 실험을 통해 맛을 보완하 자는 것이었다. 하지만 상당기간 시제품의 맛은 크게 개선되지 않았고, 그렇게 수개월을 반복한 후에 내부적으로 어느 정도 만족할만한 맛을 만들어내어 소비자 조사를 실시하였지만, 제품 의 컨셉에 대해서는 매우 긍정적인 반응을 보 였던 조사 참여자들이 막상 제품을 먹어보고는 크게 실망한 눈치였다. 무슨 맛인지 모르겠고,
맛이 밋밋하다는 반응들이 대부분이었다. 자연 그대로의 제품을 만들겠다는 당초의 생각이 무 모한 욕심이 아닐까 하는 후회와 불안감까지 생겼지만, 여기서 중단하지 않고 요플레의 글로 벌 네트워크와 요플레 중앙연구소의 협조 하에 최적의 맛을 찾아내게 되었다. 물론 소비자들의 주관적인 입맛에 따라 기존의 드링킹 요구르트 에 비해 맛이 덜하다고 느낄 수도 있겠지만, 요 리의 '조미료'에 해당하는 재료들을 쓰지 않고 만들어낸 자연의 맛으로서 빙그레가 추구한 신 제품 컨셉을 완성시키게 되었다.

신제품의 검증 과정은 빙그레의 자체적인 신 제품개발 프로세스에 따라 정성조사와 정량조 사가 실시되었으며, 설문지는 목표고객 설정과 포지셔닝의 방향성 수립을 고려해 설계하였다. 이를 바탕으로 동질성 분석, $\mathrm{MCA}$ (multiple correspondence analysis)를 실시하였다(<그림 $17>$ 참조). 이러한 분석을 통해 핵심 표적시장 을 20 대 후반 30 대 후반의 여성으로 설정하였 으며, 20 대 초반 여대생층은 비용 효율성이 떨

\section{<그림 17> 5색55感의 동질성 분석과 $\mathrm{MCA}$ (multiple correspondence analysis)}
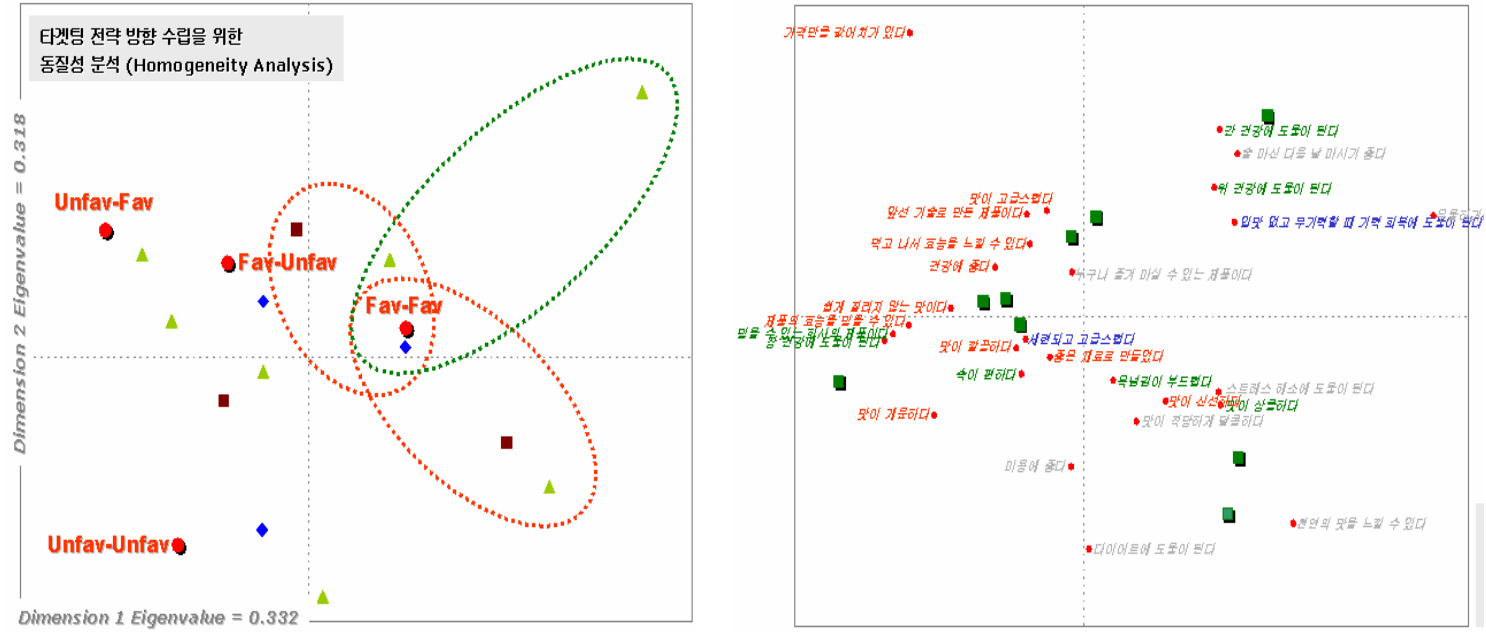
어질 것으로 예상되어 일단 광고매체 선정 등 광고전략에서 배제하고 진행하였다.

이 같은 5 색55感의 신제품 개발전략은 특정 장 기에 도움이 된다는 기능성 드링킹 요구르트제 품들의 등장과 후발 경쟁업체들의 증정행사 등 판촉위주의 푸쉬전략에 의한 수익성 악화와 같 은 열악한 경쟁 환경에서 시장을 새로운 각도 에서 재해석하고 야쿠르트가 주도하는 드링킹 요구르트 시장에서 벗어나 새로운 시장패러다 임을 창출해내기 위한 노력의 과정이었다고 볼 수 있다. 특히 제품의 기능성 편익에 토대를 둔 드링킹 요구르트시장의 경쟁패러다임을 5 색5感 이라는 브랜드명에서도 알 수 있듯이 인간의 다섯 가지 감각, 즉 감성에 소구하는 체험마케 팅으로 경쟁의 패러다임을 전환시키려는 노력 은 새로운 가치를 제공하기 위한 후발주자의 적극적인 차별화전략으로 해석할 수 있다.

\section{V. 빙그레의 향후 전략적 과제}

지금까지 빙그레 요플레의 시장 선도적 신제 품 개발전략에 대해서 살펴보았다. 향후 빙그레 요플레의 입장에서 고려해야하는 몇 가지 사항 들에 대해서 살펴보기로 하자.

첫째, 빙그레 요플레의 패밀리브랜드 전략 성 공을 위한 지속적인 브랜드 관리가 필요하다. 요플레 브랜드 자산가치 제고 및 자사의 요구 르트 브랜드 전반에 걸친 후광효과를 얻기 위 해 실시하고 있는 요플레의 패밀리브랜드전략 이 떠먹는 요구르트의 맛 중심, 저가 이미지와 드링킹 요구르트의 기능성, 고가 이미지와 상충
되어 부정적인 영향을 미칠 수 있다는 위험을 인식하고, 이 같은 부정적 효과가 최소화되고 의도했던 후광효과가 극대화될 수 있도록 지속 적인 브랜드 관리 전략이 실시되어야 한다. 장 기적으로 빙그레 요플레의 브랜드 자산을 관리 하기 위해서는 보다 정교한 전략적 관리가 필 요하다고 볼 수 있다.

둘째, 요구르트시장에 대한 시장세분화의 인 식을 보다 소비자 지향적인 컨셉으로 전환하여 새로운 시장기회를 만들어갈 필요가 있다. 현재 빙그레는 요구르트시장을 제품의 특징에 의한 떠먹는 요구르트와 드링킹 요구르트시장으로 구분하고 각 시장별 마케팅전략을 구사하고 있 다. 이는 요구르트를 구매하는 소비자들의 인식 이 두 시장을 명확하게 다른 시장으로 구분하 고 있기 때문이라고 볼 수 있다. 그러나 이 같 은 소비자들의 구분 역시 요구르트 시장의 기 업들이 실시한 마케팅 전략의 산출물이라 볼 수 있고, 이 같은 제품중심적인 시장세분화는 자칫 소비자중심의 시장세분화를 통해 획득할 수 있는 새로운 시장기회들을 잃게 만들 수도 있다. 따라서 빙그레는 소비자지향적인 시장세 분화 개념을 더욱 강화하여 소비자에 의한 새 로운 마케팅 기회와 신제품 전략을 마련해나갈 필요가 있다.

셋째, 최근에 새롭게 출시한 5 색5感의 경우 야쿠르트가 주도하는 드링킹 요구르트 시장에 서 벗어나 시장을 새로운 각도로 해석하고자 하였다. 이에 제품의 기능성 편익에 토대를 둔 기존 경쟁자들과는 달리 젊은 여성소비자를 표 적시장으로 하면서 감성에 소구하는 체험마케 팅전략을 실시하고 있다. 따라서 5 색5感의 성과 를 극대화하기 위해서는 소비자들에게 브랜드 
에 대한 어떤 특별한 느낌(혹은 감정)을 유발 시켜 브랜드 자산을 구축하기 위한 보다 정교 한 체험마케팅의 전략적 관리가 필요한 시점이 라 볼 수 있다. 이를 위해 체험마케팅의 다섯 가지 체험요소(감각, 감성, 인지, 행동, 관계)들 을 결합하여 5 색5感에 대한 고객의 총체적 체 험을 쌓기 위한 노력을 기울일 필요가 있다.

<논문 접수일: 2006. 09. 30> <게재 확정일: 2006. 09. 30>
참고문헌

이광수(2000), 도산 안창호, 범우사.

Carpenter, Gregory S. and Kent Nakamoto (1989), "Consumer Preference Formation and Pioneering Advantage", Journal of Marketing Research, 26(August), 285-298. Hauser, John R. and Steven M. Shugan (1983), "Defensive Marketing Strategies", Marketing Science, 2(Fall), 319-360.

Robert G. Cooper(1988), Winning at New Products, Perseus Books Group.

Thomas T. Nagel(2002), The strategy and Tactics of Pricing, Prentice Hall. 기타 (주)빙그레 사내자료.

www.bing.co.kr 


\title{
Marketing Strategy of New Product for Market Leader: Binggrae Yoplait Case
}

\author{
So Young Kim* \\ Heonsoo Jung** \\ Youngchan Kim***
}

\begin{abstract}
Since launching a spoonful yogurt 'Yoplait' for the first time in the nation, Binggrae Co. has established the reputation of the Yoplait brand, and secured its leading position in the yogurt market.

This study examined how Binggrae as a market pioneer (in the spoonful yogurt market) or a market follower(in the drinking yogurt market) has developed and responded to the yogurt market in which competition between companies are becoming fierce. Instead of being bound by conventional competition rules, Binggrae was found to have implemented distinctive marketing strategies for new products. That is, providing new values, the company led the market to change the paradigm of competition in the yogurt market.

Together with long-term strategic marketing plans to manage the assets of the Yoplait brand, Binggrae Yoplait is required to put continuous efforts into marketing to lead the market.
\end{abstract}

Key words: binggrae yoplait, marketing strategy, new product development, yogurt market

* Assistant Professor, Division of Business Administration, Sookmyung Women's University

** Assistant Professor, School of Business, Konkuk University

*** Professor, School of Business, Yonsei University 